\title{
A predatory soil bacterium reprograms a quorum sensing signal system to regulate antifungal weapon production in a cyclic-di-GMP-independent manner
}

\section{Li kaihuai}

Jiangsu Academy of Agricultural Sciences

\section{Gaoge Xu}

Jiangsu Academy of Agricultural Sciences

\section{Bo Wang}

Jiangsu Academy of Agricultural Sciences

\section{Guichun Wu}

Jiangsu Academy of Agricultural Sciences

\section{Rongxian Hou}

Jiangsu Academy of Agricultural Sciences

Liu Fengquan ( $\square$ fqliu20011@163.com )

Jiangsu Academy of Agricultural Sciences

\section{Article}

Keywords: Diffusible signal factor, Quorum sensing, Hybrid two-component system, Heat-stable antifungal factor, Phosphodiesterase, Lysobacter

Posted Date: March 11th, 2021

DOI: https://doi.org/10.21203/rs.3.rs-287032/v1

License: (9) This work is licensed under a Creative Commons Attribution 4.0 International License. Read Full License

Version of Record: A version of this preprint was published at Communications Biology on September 24th, 2021. See the published version at https://doi.org/10.1038/s42003-021-02660-7. 


\section{Abstract}

Soil bacteria often provide multiple weapons for eukaryotes or prokaryotes to use against predators. Diffusible signal factors (DSFs) represent a unique group of quorum sensing (QS) chemicals that modulate interspecies competition in bacteria that do not produce antibiotic-like molecules. However, the molecular mechanism by which DSF-mediated QS systems regulate weapons production for interspecies competition remains largely unknown in soil biocontrol bacteria. In this study, we found that the necessary QS system component protein RpfG from Lysobacter, in addition to being a cyclic dimeric GMP (c-di-GMP) phosphodiesterase (PDE), regulates the biosynthesis of an antifungal weapon (heat-stable antifungal factor, HSAF), which does not appear to depend on the enzymatic activity. Interestingly, we showed for the first time that RpfG interacts with three hybrid two-component system (HyTCS) proteins, $\mathrm{HtsH} 1, \mathrm{HtsH} 2$, and $\mathrm{HtsH}$, to regulate HSAF production in Lysobacter. In vitro studies showed that each of these proteins interacted with RpfG, which reduced the PDE activity of RpfG. Finally, we showed that the cytoplasmic proportions of these proteins depended on their phosphorylation activity and binding to the promoter controlling the genes implicated in HSAF synthesis. These findings reveal a new mechanism of DSF signalling in antifungal weapon production in soil bacteria.

\section{Introduction}

Interspecies competition plays a key role in shaping microbial populations and determining the bacterial species that are dominant in a given niche ${ }^{1}$. To fend off these competitors, bacteria deploy various toxins as weapons against eukaryotic or prokaryotic predators. The diffusible signal factor (DSF) family signals are important for maintaining the interspecies competitive fitness of bacteria ${ }^{2}$. The DSF-family signals interfere with the morphological transition of Candida albicans through inter-kingdom communication ${ }^{3,4}$.

DSFs represent a new class of widely conserved quorum sensing (QS) signals with a fatty acid moiety that regulate various biological functions in pathogenic and beneficial environmental bacteria ${ }^{5,6}$. The Rpf gene cluster is important for the DSF signalling network in bacteria, and the role of the RpfF and $\mathrm{RpfC/RpfG}$ two-component system (TCS) in this gene cluster in DSF production and signal transduction has been well documented ${ }^{5,7-10}$. A previous study revealed that RpfG contains both an N-terminal response regulator domain and a C-terminal HD-GYP domain ${ }^{11}$. The activated HD-GYP domain of RpfG has cyclic dimeric GMP (c-di-GMP) phosphodiesterase (PDE) activity that can degrade c-di-GMP, an inhibitory ligand of the global transcription factor Clp. Consequently, derepressed Clp drives the expression of several hundred genes, including those encoding virulence factor production in the plant pathogen Xanthomonas ${ }^{12-15}$. However, the regulatory mechanism of the DSF-mediated QS system remains unknown in bacteria that are beneficial to plants.

Lysobacter enzymogenes is a nonpathogenic strain that was used to control crop fungal diseases known for the synthesis of an antifungal weapon (heat-stable antifungal factor, HSAF) that exhibits inhibitory 
activity against a wide range of fungal species ${ }^{16-23}$. Our previous work revealed that RpfG affects production of the antifungal weapon HSAF in L. enzymogenes ${ }^{24}$. However, the molecular mechanism by which RpfG regulates the biosynthesis of HSAF remains unknown.

In the present study we found that unlike the Xanthomonas RpfC/RpfG-Clp signalling pathway, the $L$. enzymogenes RpfG protein interacts with three hybrid two-component system (HyTCS) proteins (HtsH1, $\mathrm{HtsH} 2, \mathrm{HtsH} 3$ ) to regulate the production of the antifungal weapon HSAF and describe for the first time their regulatory functions in soil bacteria. The $\mathrm{HtsH} 1, \mathrm{HtsH} 2$, and $\mathrm{HtsH} 3$ functions likely represent a common mechanism that helps establish signalling specificity in bacteria for interspecies competition.

\section{Results}

\section{The HD-GYP domain of RpfG has PDE activity and can degrade c-di-GMP}

Sequence analysis revealed that the HD-GYP domain contains all residues essential for PDE activities, thus suggesting that RpfG may be a PDE enzyme. To obtain direct evidence for the biochemical function of RpfG, recombinant N-terminal maltose binding protein (MBP) RpfG (designated RpfG-MBP) was produced. The proteins had a monomeric molecular weight of $71 \mathrm{kDa}$ and were purified by dextrin sepharose high performance to obtain preparations that exhibited by SDS-gel electrophoresis (Figure 1A). This RpfG-MBP protein was able to degrade the model substrate c-di-GMP to 5'-pGpG, consistent with its PDE activity (Figure 1B). Quantitative analysis revealed that RpfG-MBP exhibited a high level of activity for the degradation of c-di-GMP with $100 \%$ degraded at 5 min after initiation of the reaction in comparison to the MBP enzyme as a control (Figure 1C). To better understand the roles of the HD-GYP domain in RpfG function, we substituted the RpfG residues His-190, Asp-191, Gly-253, Tyr-254, and Pro255 of the HD-GYP signature motif with alanine (Ala) by site-directed mutagenesis into constructs expressing the RpfG-H190A-MBP, RpfG-D191A-MBP, RpfG-G253A-MBP, and RpfG-P255A-MBP proteins. We tested the c-di-GMP PDE activity of these mutant proteins. Our results showed that point mutations of the His-190, Asp-191, Gly-253, and Pro-255 residues in RpfG almost abolished PDE activity (Figure 1B, C). These data suggest that RpfG has PDE activity and that the HD-GYP individual residues are required for full PDE activity of RpfG in vivo.

\section{HSAF production does not depend on RpfG PDE enzymatic activity}

Our earlier work revealed that RpfG affects HSAF production in L. enzymogenes ${ }^{24}$. However, the molecular mechanism by which RpfG regulates HSAF synthesis remains unknown. Since RpfG, as a PDE enzyme, was able to degrade the substrate c-di-GMP to 5'-pGpG, we investigated whether RpfG PDE activity played a major role on controlling the production of in L. enzymogenes. We quantified HSAF production in the $\triangle r p f G$ mutant and complementary strain $(\triangle r p f G / r p f G)$ by HPLC. We found that HSAF production in the $\triangle r p f G$ mutant strain was completely suppressed (Figure $2 \mathrm{~A}$ ). The complementary strain $\Delta r p f G / r p f G$ yielded HSAF at the level of the wild-type strain (Figure $2 A$ ). These results were similar to those of the above research ${ }^{24}$. To examine the relationship between the regulatory and enzymatic 
activities of RpfG, mutations at the conserved His-190, Asp-191, Gly-253, Tyr-254, and Pro-255 of the HDGYP signature motif with alanine (Ala) were examined by site-directed mutagenesis. We tested HSAF production in the $\triangle r p f G$ mutant strain carrying plasmids encoding these mutant proteins. The strains expressing the RpfG H190A, D191A, G253A, Y254A, and P255A mutant proteins showed increased HSAF production compared with the $\triangle r p f G$ mutant strain. These results were superior to those of the complementary strain $\triangle r p f G / r p f G$. Importantly, the $\triangle r p f G$ mutant strain and complemented strains ( $\Delta r p f G / r p f G, \Delta r p f G / r p f G$ H190A, $\Delta r p f G / r p f G$ D191A, $\Delta r p f G / r p f G$ G253A, $\Delta r p f G / r p f G$ Y254A, and $\triangle r p f G / r p f G$ P255A) did not impair bacterial growth (Figure 2B, C). As described above, His-190, Asp-191, Gly-253, Tyr-254, and Pro-255 were found to be critical for the PDE activity of RpfG (Figure 1), implying that HSAF is regulated in a PDE independent manner. To test this prediction, we compared intracellular Cdi-GMP concentrations in the $\triangle r p f G$ mutant and the wild type and in the HSAF-production medium (10\% TSB). We found that the concentration in the $\triangle r p f G$ mutant did not significantly change c-di-GMP production compared with the wild-type strain (Figure 2D). These findings indicated that the regulatory activity of RpfG does not depend on its PDE enzymatic activity against c-di-GMPs.

\section{RpfG binds directly to the HyTCS protein HtsHs}

The above findings confirmed that RpfG does not regulate HSAF biosynthesis through the c-di-GMP signalling pathway, indicating that RpfG might regulate HSAF biosynthesis through interactions with other proteins in L. enzymogenes. To further explore the mechanisms underlying the contribution of RpfG to HSAF production, we used a bioinformatic tool (STRING) to identify potential interactors for RpfG; these represent interactions that possibly lead to alterations in HSAF synthesis. We discovered that RpfG interacts with three HyTCS proteins through bioinformatics predictions (Figure S1A). We designated the HyTCS protein $\mathrm{HtsH}$ (hybrid two-component signalling system regulating $\underline{\mathrm{H} S A F}$ production) based on the findings of this study. To verify the operon structure of $h t s H s$ for in-depth genetic analyses, a series of RTPCR primers (Table S2 and Figure S1B) were designed to determine whether there are intergenic transcripts crossing the adjacent genes. As shown in Figure S1C, Le3071 (htsH1), Le3072 (htsH2), and Le3073 (htsH3) likely constitute a single transcription unit because the corresponding intergenic transcripts were successfully amplified. Le3071 ( $h t s H 1)$, Le3072 ( $h t s H 2)$, and Le3073 ( $h t s H 3$ ) encode a group of typical HyTCS proteins with pfam Reg_prop, pfam Y-Y-Y, HisKA, HATPase_c, and Response_reg domains. All three HyTCS proteins contain one predicted transmembrane region (Figure S1D). We examined the alignments of three HyTCS proteins ( $\mathrm{HtsH} 1, \mathrm{HtsH} 2$, and $\mathrm{HtsH} 3)$, and the results showed that the $\mathrm{HtsH} 1$ protein shares $50 \%$ and $53 \%$ identity with $\mathrm{HtsH} 2$ and $\mathrm{HtsH} 3$, respectively. We also aligned $\mathrm{HtsH} 2$ with $\mathrm{HtsH} 3$, and the identity values were $50 \%$ (Figure S2).

To examine whether RpfG could directly bind to the HyTCS proteins ( $\mathrm{HtsH} 1, \mathrm{HtsH} 2$ and $\mathrm{HtsH} 3$ ), we used a pull-down assay using $E$. coli-expressed proteins in vitro. We purified recombinant RpfG-MBP, and the cytoplasmic fragments of $\mathrm{HtsH} 1$, $\mathrm{HtsH} 2$, and $\mathrm{HtsH} 3$ (HtsH1C-Flag-His, $\mathrm{HtsH} 2 \mathrm{C}-\mathrm{HA}-\mathrm{His}$, and HtsH3C-MycHis, respectively) from E. coli (Figure 1A and Figure S3). First, we tested the ability of RpfG-MBP to pull down HtsH1C-Flag-His, HtsH2C-HA-His, and HtsH3C-Myc-His. Finally, we confirmed the interaction between RpfG and $\mathrm{HtsH} 1, \mathrm{HtsH} 2$ or $\mathrm{HtsH} 3$ using pull down assays (Figure 3A). Conversely, we examined 
the ability of HtsH1C-Flag-His, HtsH2C-HA-His, and HtsH3C-Myc-His to pull down RpfG-MBP and observed a positive signal (Figure 3B-D). Second, we used surface plasmon resonance (SPR) to measure the possible binding events between the RpfG and $\mathrm{HtsH} 1, \mathrm{HtsH} 2$, or $\mathrm{HtsH} 3$ proteins. The RpfG-MBP sensor physically bound $\mathrm{HtsH} 1 \mathrm{C}$-Flag-His with a binding constant $\left(\mathrm{K}_{\mathrm{D}}\right)$ of $0.06675 \mu \mathrm{M}$ (Figure 3E), suggesting an intermediate level of protein-protein interaction. We also confirmed direct binding between the RpfG-MBP and $\mathrm{HtsH} 2 \mathrm{C}-\mathrm{HA}-\mathrm{His}$ or HtsH3C-Myc-His proteins by SPR $\left(\mathrm{K}_{\mathrm{D}}=0.2998 \mu \mathrm{M}\right.$ or $\mathrm{K}_{\mathrm{D}}=0.1678 \mu \mathrm{M}$, respectively $)$ (Figure 3F-G). Additionally, the SPR assay revealed that HtsH1C-Flag-His bound to HtsH2C-HA-His or $\mathrm{HtsH} 3 \mathrm{C}-\mathrm{Myc}-\mathrm{His}$ with reasonably high affinity $\left(\mathrm{K}_{\mathrm{D}}=0.09619 \mu \mathrm{M}\right.$ or $\mathrm{K}_{\mathrm{D}}=0.1597 \mu \mathrm{M}$, respectively $)$ and revealed that $\mathrm{HtsH} 2 \mathrm{C}-\mathrm{HA}-\mathrm{His}$ bound $\mathrm{HtsH} 3 \mathrm{C}-\mathrm{Myc}-\mathrm{His}$ with a $\mathrm{K}_{\mathrm{D}}$ value of $0.1782 \mu \mathrm{M}$ (Figure S4). Taken together, these experiments demonstrate that RpfG directly interacts with $\mathrm{HtsH} 1$, $\mathrm{HtsH} 2$ or $\mathrm{HtsH} 3$ proteins in vitro.

\section{HtsHs inhibits the PDE enzymatic activity of RpfG}

We wondered whether RpfG and $\mathrm{HtsH} 1, \mathrm{HtsH} 2$, or $\mathrm{HtsH} 3$ interactions affect the PDE activity of RpfG. To test this hypothesis, we used a biochemical assay in which c-di-GMP hydrolysis by RpfG-MBP was assayed in the absence or presence of $\mathrm{HtsH} 1, \mathrm{HtsH} 2$, or $\mathrm{HtsH}$, ranging from $0 \mu \mathrm{M}$ to $32 \mu \mathrm{M}$. The results of the assay showed that the PDE activity of RpfG-MBP was lower in the presence than in the absence of $\mathrm{HtsH} 1 \mathrm{C}$-Flag-His, HtsH2C-HA-His, or HtsH3C-Myc-His (Figure 4). Therefore, the results of the assays suggested that $\mathrm{HtsH} 1, \mathrm{HtsH}$, and $\mathrm{HtsH} 3$ inhibited the PDE enzymatic activity of RpfG. This result further confirms that the ability of RpfG to regulate HSAF production does not depend on its PDE enzymatic activity against c-di-GMP in L. enzymogenes.

\section{Deletion of $h t s H 1, h t s H 2$, and $h t s H 3$ resulted in decreased HSAF production}

The above studies indicated that RpfG might regulate HSAF biosynthesis by interacting with $\mathrm{HtsHs}$ $(\mathrm{HtsH} 1, \mathrm{HtsH} 2$, and $\mathrm{HtsH} 3)$ in L. enzymogenes. To identify the physiological functions of $\mathrm{HtsH} 1, \mathrm{HtsH}$, and $\mathrm{HtsH} 3$ in HSAF production, the genes $h t s H 1$ (Le3071), htsH2 (Le3072), and htsH3 (Le3073) were deleted using a two-step homologous recombination approach to construct the single knockout strains $\Delta h t s H 1, \Delta h t s H 2$, and $\Delta h t s H 3$; the double mutant knockout strains $\Delta h t s H 12, \Delta h t s H 13$, and $\Delta h t s H 23$; and the triple knockout strain $\Delta h t s H 123$. Subsequently, we quantified HSAF production in all the above mutant strains described by HPLC. We found that $\Delta h t s H 1, \Delta h t s H 2$, and $\Delta h t s H 3$ exhibited slightly decreased HSAF levels. However, the double-mutant strains $\Delta h t s H 12, \Delta h t s H 13, \Delta h t s H 23$, and triplemutant strain $\Delta h t s H 123$ exhibited a significant decrease in HSAF levels compared with the wild-type levels (Figure $5 \mathrm{~A}$ ). To determine the role of $\mathrm{HtsH} 1, \mathrm{HtsH} 2$, and $\mathrm{HtsH} 3$ in the regulation of HSAF biosynthesis, we complemented $\Delta h t s H 1, \Delta h t s H 2, \Delta h t s H 3$, the double-mutant strains $\Delta h t s H 12, \Delta h t s H 13$, $\Delta h t s H 23$, and the triple-mutant strain $\Delta h t s H 123$ with plasmid-borne $h t s H 1, h t s H 2, h t s H 3, h t s H 12, h t s H 13$, $h t s H 23$, and $h t s H 123 . \mathrm{HSAF}$ production in the complemented strains $(\Delta h t s H 1 / h t s H 1, \Delta h t s H 2 / h t s H 2$, $\Delta h t s H 3 / h t s H 3, \Delta h t s H 12 / h t s H 12, \Delta h t s H 13 / h t s H 13, \Delta h t s H 23 / h t s H 23$, and $\Delta h t s H 123 / h t s H 123)$ restored HSAF biosynthesis compared with the wild-type levels (Figure 5A). Importantly, $\Delta h t s H 1, \Delta h t s H 2$ and $\Delta h t s H 3$; the double-mutant strains $\Delta h t s H 12, \Delta h t s H 13$, and $\Delta h t s H 23$; and the triple-mutant strain 
$\Delta h t s H 123$ did not impair bacterial growth (Figure 5B, C), implying that $\mathrm{HtsH} 1, \mathrm{HtsH} 2$ and $\mathrm{HtsH} 3$ play a specific role in regulating HSAF production.

\section{$\mathrm{HtsH} 1, \mathrm{HtsH}$, and $\mathrm{HtsH} 3$ positively regulate HSAF biosynthesis gene expression}

Earlier, we found that deletion of $h t s H 1, h t s H 2$ and $h t s H 3$ resulted in decreased HSAF production. Thus, we wondered whether $\mathrm{HtsH} 1, \mathrm{HtsH}$, and $\mathrm{HtsH} 3$ might directly target $\mathrm{HSAF}$ biosynthesis gene promoters. To test this hypothesis, we performed an E. coli-based one-hybrid assay. As shown in Figure 6A, HtsH1, $\mathrm{HtsH} 2$, and $\mathrm{HtsH} 3$ directly bound to the promoter of the first gene lafB in the HSAF biosynthesis operon (p/afB).

Next, we tested the ability of $\mathrm{HtsH} 1, \mathrm{HtsH} 2$, and $\mathrm{HtsH} 3$ to bind to the lafB promoter, using an electrophoretic mobility shift assay (EMSA). A PCR-amplified $590 \mathrm{bp}$ DNA fragment from the plafB was used as a probe. The addition of purified HtsH1C-Flag-His, $\mathrm{HtsH} 2 \mathrm{C}-\mathrm{HA}-\mathrm{His}$, and $\mathrm{HtsH} 3 \mathrm{C}-\mathrm{Myc}-\mathrm{His}$ protein, ranging from $0 \mu \mathrm{M}$ to $10 \mu \mathrm{M}$, to the reaction mixtures $\left(20 \mu \mathrm{L}\right.$ and at $\left.28^{\circ} \mathrm{C}, 25 \mathrm{~min}\right)$ caused a shift in the mobility of the plafB DNA fragment, and the EMSA revealed strong $\mathrm{HtsH} 1, \mathrm{HtsH} 2$, and $\mathrm{HtsH} 3$ binding with the plafB probe in a dose-dependent manner (Figure 6B-D). We quantified the binding affinity of $\mathrm{HtsH}$, $\mathrm{HtsH} 2$, and $\mathrm{HtsH} 3$ to the HSAF operon promoter. In an SPR analysis, $\mathrm{HtsH} 1 \mathrm{C}$-Flag-His directly bound to the promoter of the HSAF biosynthesis gene (p/afB) with high affinity $\left(\mathrm{K}_{\mathrm{D}}=0.5356 \mu \mathrm{M}\right)$ (Figure 6E). In addition, $\mathrm{HtsH} 2 \mathrm{C}-\mathrm{HA}-\mathrm{His}$ and $\mathrm{HtsH} 3 \mathrm{C}-\mathrm{Myc}-\mathrm{His}$ bound to $\mathrm{plafB}$ with $\mathrm{K}_{\mathrm{D}}$ values of $1.379 \mu \mathrm{M}$ and $0.2491 \mu \mathrm{M}$, respectively (Figure 6F-G). The results demonstrated that $\mathrm{HtsH} 1, \mathrm{HtsH} 2$, and $\mathrm{HtsH} 3$ could directly target the promoters of the HSAF biosynthesis gene.

Based on the above results, we compared the transcriptome profiles of the wild-type strain and the $h t s H s$ mutants ( $\Delta h t s H 1, \Delta h t s H 2, \Delta h t s H 3, \Delta h t s H 12, \Delta h t s H 13, \Delta h t s H 23$, and $\Delta h t s H 123)$ by RNA-Seq and observed changes in the expression levels of several hundred genes (Table S3). We then performed trend analysis of the differential gene expression and found that the amounts of HSAF biosynthesis gene cluster mRNA were constitutively decreased in the $h t s H s$ mutants ( $\triangle h t s H 1, \Delta h t s H 2, \Delta h t s H 3, \Delta h t s H 12$, $\Delta h t s H 13, \Delta h t s H 23$ and $\Delta h t s H 123$ ) (Figure S5). Using quantitative RT-PCR (qRT-PCR), We measured the mRNA abundance of lafB in the htsHs mutants ( $\Delta h t s H 1, \Delta h t s H 2, \Delta h t s H 3, \Delta h t s H 12, \Delta h t s H 13, \Delta h t s H 23$ and $\Delta h t s H 123$ ) and found that it was reduced compared to that in the wild type (Figure S6).

Taken together, these results suggested that $\mathrm{HtsH} 1, \mathrm{HtsH} 2$, and $\mathrm{HtsH} 3$ can directly target the promoters of the HSAF biosynthesis genes to increase their expression and HSAF production by L. enzymogenes.

\section{Phosphorylated $\mathrm{HtsH} 1, \mathrm{HtsH} 2$, and $\mathrm{HtsH} 3$ positively regulate HSAF biosynthesis}

Since $\mathrm{HtsH} 1, \mathrm{HtsH} 2$ and $\mathrm{HtsH} 3$ function as a group of HyTCS proteins, we explored whether they could directly target plafB depending on its phosphorylation activity in L. enzymogenes. To achieve this goal, we assessed the phosphorylation levels of these proteins with calf intestine alkaline phosphatase (CIAP) in the reaction mixtures $\left(20 \mu \mathrm{L}, 28^{\circ} \mathrm{C}, 60 \mathrm{~min}\right)$. Using $\mathrm{Mn}^{2+}$-Phos-tag SDS-PAGE, we showed that the phosphorylation levels of HtsH1 C-Flag-His, HtsH2C-HA-His, and HtsH3C-Myc-His decreased upon CIAP 
treatment (Figure 7A-C). To test the effect of $\mathrm{HtsH} 1-, \mathrm{HtsH} 2-$, or $\mathrm{HtsH} 3$-mediated phosphorylation on the function of the target plafB, EMSAs were performed with the same experimental conditions. The EMSAs revealed that the amount of probes bound to HtsH1C-Flag-His, HtsH2C-HA-His, and HtsH3C-Myc-His decreased with increasing amounts of CIAP (Figure 7D-F). The above findings indicated that HtsH1, $\mathrm{HtsH} 2$ and $\mathrm{HtsH} 3$ could directly regulate HSAF biosynthesis gene expression depending on their phosphorylation activity in L. enzymogenes.

\section{RpfG- and HtsH1-, HtsH2-, and $\mathrm{HtsH} 3$-dependent regulatory patterns are present in a wide range of bacterial species}

By BLAST analysis of the nonredundant protein sequence ( $\mathrm{Nr}$ ) database of the National Center for Biotechnology Information (NCBI), we found that RpfG, the rpf cluster, and $\mathrm{HtsH} 1, \mathrm{HtsH} 2$, and $\mathrm{HtsH} 3$ were present not only in the genomes of Lysobacter species, but also Xanthomonas species (Figure S7). These findings suggest that RpfG-, $\mathrm{HtsH} 1-, \mathrm{HtsH} 2$-, and $\mathrm{HtsH} 3-d e p e n d e n t$ regulatory patterns are conserved mechanisms in Lysobacter and Xanthomonas.

\section{Discussion}

In previous studies, we and our collaborators have shown that quorum sensing (QS) was employed by $L$. enzymogenes to affect production of the antifungal weapon HSAF ${ }^{6,25}$. However, the mechanism through which QS coordinates the synthesis of HSAF remains unknown. RpfG, as a necessary component protein of the DSF mediated QS signal transduction system, contains a C-terminal HD-GYP domain that can affect production of the antifungal weapon HSAF in L. enzymogenes ${ }^{11,25}$. However, how RpfG regulates the synthesis of HSAF remains incompletely studied. The results of the present study provide biochemical, genetic, and biophysical evidence to demonstrate for the first time that $L$. enzymogenes reprograms the QS signal system that RpfG interacts with HtsHs to regulate the biosynthesis of the antifungal antibiotic HSAF. $\mathrm{HtsH} 1, \mathrm{HtsH} 2$, and $\mathrm{HtsH} 3$ regulate the expression of the synthetic genes of the antifungal weapon HSAF depending on their phosphorylation (Figure 8).

HD-GYP domain proteins are c-di-GMP PDEs that can degrade c-di-GMP ${ }^{12}$. However, the role of the HDGYP domain of RpfG in the degradation of c-di-GMP in L. enzymogenes has remained unelucidated. Therefore, we tested the PDE activity of RpfG and successfully showed that it was able to degrade the model substrate c-di-GMP to 5'-pGpG. To test whether the HD-GYP motif was important for catalytic activity in RpfG, we constructed RpfG mutant proteins (RpfG-H190A-MBP, RpfG-D191A-MBP, RpfG-G253AMBP, and RpfG-P255A-MBP). We tested the c-di-GMP PDE activity of these mutant proteins and suggested that the HD-GYP domain was required for full PDE activity of RpfG in vivo. It is generally speculated that the PDE activity of HD-GYP domain proteins is to degrade c-di-GMP to GMP $11,26,27$. However, we showed that the activity of the HD-GYP domain of RpfG is involved in the degradation of cdi-GMP to 5'-pGpG. 
Intriguingly, we found that the strains expressing the RpfG H190A, D191A, G253A, Y254A, and P255A mutant proteins resulted in increased HSAF production compared with the $\triangle r p f G$ mutant strain. Importantly, we found that the concentration of the $\triangle r p f G$ mutant did not significantly change c-di-GMP production compared with of the wild-type strain in the antifungal weapon HSAF-production medium (10\% TSB). These data demonstrated that the regulatory activity of RpfG does not depend on its PDE enzymatic activity. This is the first report showing that a PDE does not depend on its c-di-GMP-degrading activity to regulate a downstream pathway. Thus, we wondered whether RpfG regulates HSAF synthesis through interactions with other proteins in L. enzymogenes.

Bioinformatics predictions have shown that RpfG may interact with three HyTCS proteins ( $\mathrm{HtsH} 1, \mathrm{HtsH}$, and $\mathrm{HtsH} 3$ ). Then, we used pull-down and SPR to demonstrate the binding events between the RpfG and $\mathrm{HtsH} 1$, HtsH2, or $\mathrm{HtsH} 3$ proteins. Notably, RpfG and $\mathrm{HtsH} 1, \mathrm{HtsH} 2$, or $\mathrm{HtsH} 3$ interactions affect the PDE activity of RpfG. However, how RpfG affects $\mathrm{HtsH} 1, \mathrm{HtsH} 2$, or $\mathrm{HtsH} 3$ remains unknown. We speculate that RpfG may affect $\mathrm{HtsH} 1, \mathrm{HtsH} 2$, or $\mathrm{HtsH} 3$ autophosphorylation. However, we could not obtain the fulllength $\mathrm{HtsH} 1, \mathrm{HtsH} 2$, and $\mathrm{HtsH} 3$ proteins, so further clarification of these possible mechanisms will help elucidate the mechanism underlying the RpfG interaction with $\mathrm{HtsH} 1, \mathrm{HtsH} 2$, or $\mathrm{HtsH}$. Moreover, we found that $h t s H 1, h t s H 2$, and $h t s H 3$ likely constitute a single transcription unit. HyTCS-based regulation may be crucial for responding to environmental changes and finely tuning gene expression ${ }^{28-31}$. However, the biological function of three consecutive HyTCS proteins has not been reported in bacteria.

In this study, we found that the in-frame deletion of the $h t s H 1$, htsH2, and $h t s H 3$ coding sequences significantly decreased HSAF production. Thus, we speculate that RpfG may interact with three HyTCS proteins to coordinate HSAF production in L. enzymogenes. To test this hypothesis, we performed an $E$. coli-based one-hybrid assay and EMSA. The results demonstrated that $\mathrm{HtsH} 1, \mathrm{HtsH}$, and $\mathrm{HtsH} 3$ could directly target the promoters of HSAF biosynthesis genes. We further analysed the transcription level of HSAF biosynthesis-related genes in $h t s H 1$, htsH2, and $h t s H 3$ mutants. Knockout of $h t s H 1$, $h t s H 2$, and $h t s H 3$ significantly reduced the transcription level of the antifungal weapon HSAF biosynthesis genes. These results suggest that $\mathrm{HtsH} 1, \mathrm{HtsH} 2$, and $\mathrm{HtsH} 3$ can directly regulate $\mathrm{HSAF}$ biosynthesis gene expression and increase production of the antifungal weapon HSAF in L. enzymogenes.

Phosphorylation of TCS is critical for regulating the expression of downstream genes ${ }^{32-34}$. Phosphorylated $\mathrm{HtsH} 1, \mathrm{HtsH}$, and $\mathrm{HtsH} 3$ positively regulate $\mathrm{HSAF}$ biosynthesis and argue with the existing literature concerning whether this is a common route of gene expression regulation. We used $\mathrm{Mn}^{2+}$-Phos-tag SDS-PAGE and EMSA to show that $\mathrm{HtsH} 1, \mathrm{HtsH}$, and $\mathrm{HtsH} 3$ target p/afB depending on their phosphorylation activity. In this study, we report for the first time the biological functions of the three HyTCS proteins $\mathrm{HtsH} 1, \mathrm{HtsH}$, and $\mathrm{HtsH} 3$ in the regulation of antibiotic biosynthesis.

One of the notable results of this study is that $\mathrm{RpfG}$, and $\mathrm{HtsH} 1, \mathrm{HtsH} 2$ and $\mathrm{HtsH} 3$ regulatory patterns seem to be conserved mechanisms in Lysobacter and Xanthomonas. To our knowledge, RpfG represents a unique example of a c-di-GMP metabolic enzyme that directly interacts with three HyTCS proteins ( $\mathrm{HtsH} 1, \mathrm{HtsH} 2$ and $\mathrm{HtsH} 3)$ to regulate HSAF biosynthesis. 


\section{Experimental Procedures}

\section{Bacterial strains, plasmids, and growth conditions}

The strains and plasmids used in this study are shown in Table S1. E. coli strains were grown in LuriaBertani medium ( $10 \mathrm{~g} / \mathrm{L}$ tryptone, $5 \mathrm{~g} / \mathrm{L}$ yeast extract, $10 \mathrm{~g} / \mathrm{L} \mathrm{NaCl}, \mathrm{pH} 7.0$ ) at $37^{\circ} \mathrm{C}$. L. enzymogenes strains were grown at $28^{\circ} \mathrm{C}$ in Luria-Bertani medium and $10 \%$ TSB. For the preparation of culture media, tryptone, peptone, beef extract, and yeast extract were purchased from Sangon Biotech (Shanghai, China). When required, antibiotics were added ( $30 \mu \mathrm{g} / \mathrm{mL}$ kanamycin sulphate, $50 \mu \mathrm{g} / \mathrm{mL}$ gentamycin) to the E. colior $L$. enzymogenes cultures. The bacterial growth in liquid medium was determined by measuring the optical density at $600 \mathrm{~nm}$ (OD600) using a Bioscreen-C Automated Growth Curves Analysis System (OY Growth Curves FP-1100-C, Helsinki, Finland).

\section{Site-directed mutagenesis}

Site-directed mutagenesis and essentiality testing were performed as described previously ${ }^{35}$. To obtain the RpfG mutant proteins and $r p f G$ site-directed mutant strains, plasmids harbouring mutations in $r p f G$ were constructed. For example, to obtain the H190A mutation in RpfG, approximately 500-bp DNA fragments flanking the $r p f G$ gene were amplified with $P f u$ DNA polymerase using $L$. enzymogenes genomic DNA as template and either MBP-rpfG P1 and rpfG H190A P1 (for the Up rpfG H190A mutant), or $r p f G$ H190A P1 and MBP-rpfG P2 (for the Down rpfG H190A mutant) as the primers (Table S2). The fragments were connected by overlap PCR using the primers MBP-rpfG P1 and MBP-rpfG P2. The fused fragment was digested with $\mathrm{BamH} I$ and Hindlll and inserted into pMAl-p2x to obtain the plasmid pMAl$r p f G$ H190A. The other four site-directed mutant plasmids (D191A, G253A, Y254A, and P255A) were constructed using a similar method.

\section{Protein expression and purification}

Protein expression and purification were performed as described previously ${ }^{36}$. To clone the $r p f G$ gene, genomic DNA extracted from L. enzymogenes was used for PCR amplification using Pfu DNA polymerase, and the primers are listed in Table S2. The PCR products were inserted into pMAl-p2x to produce the plasmids pMAl-rpfG. The $r p f G$ gene was verified by nucleotide sequencing by Genscript (Nanjing, Jiangsu, China). Le $r p f G$ and $r p f G$ site-directed mutants with a vector-encoded maltose binding protein in the N-terminus were expressed in E. coli BL21 (DE3) and purified with dextrin sepharose high performance (Qiagen, Chatsworth, CA, USA) using an affinity column (Qiagen). The protein purity was monitored by SDS-PAGE. His $_{6}$-tagged protein expression and purification were performed as described previously ${ }^{35-37}$.

\section{PDE activity assays in vitro}

The PDE activity assay was performed essentially as described earlier ${ }^{24}$. Briefly, $2 \mu \mathrm{M} \mathrm{MBP-RpfG}$ or its derivatives were tested in buffer containing $60 \mathrm{mM}$ Tris- $\mathrm{HCl}(\mathrm{pH} 7.6), 50 \mathrm{mM} \mathrm{NaCl}, 10 \mathrm{mM} \mathrm{MnCl}$, and 10 
$\mathrm{mM} \mathrm{MgCl}_{2}$. The reaction was started by the addition of $100 \mu \mathrm{M} \mathrm{c}$-di-GMP. All reaction mixtures were incubated at $28^{\circ} \mathrm{C}$ for 5 to $60 \mathrm{~min}$, followed by boiling for $10 \mathrm{~min}$ to stop the reaction. The samples were filtered through a $0.2 \mu \mathrm{M}$ pore size cellulose-acetate filter, and $20 \mu \mathrm{l}$ of each sample was loaded onto a reverse-phase $\mathrm{C} 18$ column and separated by HPLC. The separation protocol involved two mobile phases, $100 \mathrm{mM} \mathrm{KH}_{2} \mathrm{PO}_{4}$ plus $4 \mathrm{mM}$ tetrabutylammonium sulphate $(\mathrm{A})$ and $75 \% \mathrm{~A}+25 \%$ methanol (B).

\section{C-di-GMP extraction and quantification}

C-di-GMP extraction and quantification were performed as described previously ${ }^{24}$. Cultures were grown in $10 \%$ TSB at $28^{\circ} \mathrm{C}$ until the OD 600 reached 1.5 based on the growth curve. Cells from $2 \mathrm{~mL}$ of the culture were harvested for protein quantification by BCA (TransGen, China). Cells from $8 \mathrm{~mL}$ of culture were used for c-di-GMP extraction using $0.6 \mathrm{M} \mathrm{HClO}_{4}$ and $2.5 \mathrm{M} \mathrm{K}_{2} \mathrm{CO}_{3}$. The samples were subjected to $0.22 \mu \mathrm{m}$ Mini-Star filtration, and the filtrate was concentrated to $100 \mu \mathrm{L}$ for liquid chromatography-tandem mass spectrometry (LC-MS/MS) analysis on an AB SCIEX QTRAP 6500 LC-MS/MS system (AB SCIEX, USA). The separation protocol involved two mobile phases, buffer $A: 100 \mathrm{mM}$ ammonium acetate plus $0.1 \%$ acetic acid; buffer B: $100 \%$ methanol. The gradient system was from $90 \%$ buffer $A$ and $10 \%$ buffer $B$ to $20 \%$ buffer $A$ and $80 \%$ buffer $B$. The running time was $9 \mathrm{~min}$, and the flow rate was $0.3 \mathrm{~mL} / \mathrm{min}$.

\section{Gene deletion and complementation}

The in-frame deletions in L. enzymogenes $\mathrm{OH} 11$ were generated via double-crossover homologous recombination as described previously ${ }^{24,35}$ using the primers listed in Table S2. In brief, the flanking regions of each gene were PCR-amplified and cloned into the suicide vector pEX18Gm (Table S1). The deletion constructs were transformed into the wild-type strain by electroporation, and gentamycin was used to select for integration of the nonreplicating plasmid into the recipient chromosome. A singlecrossover integrant colony was spread on LB medium without gentamycin and incubated at $28^{\circ} \mathrm{C}$ for 3 days, and after appropriate dilution, the culture was spread on LB plates containing $15 \%$ sucrose. Colonies sensitive to gentamycin were screened by PCR using the primers listed in Table S2, and the gene deletion strains were obtained.

For gene complementation constructs, DNA fragments containing the full-length genes along with their promoters were PCR amplified and cloned into the versatile plasmid pBBR1MCS $5^{38}$. The resulting plasmids were transferred into the $L$. enzymogenes strain by electroporation, and the transformants were selected on LB plates containing $\mathrm{Gm}$.

\section{RNA-Seq}

The RNA-Seq assay was performed as described previously ${ }^{39,40}$. Briefly, the wild-type, $\Delta h t s H 1, \Delta h t s H 2$, $\Delta h t s H 3, \Delta h t s H 12, \Delta h t s H 13, \Delta h t s H 23$, and $\Delta h t s H 123$ mutant strains were grown in $10 \%$ TSB medium at $28^{\circ} \mathrm{C}$, and their cells were collected when the OD600 reached 1.0 based on the growth curve. The collected cells were used for RNA extraction by the TRIzol-based method (Life Technologies, CA, USA), and RNA degradation and contamination were monitored on $1 \%$ agarose gels. Then, clustering and sequencing 
were performed by Genedenovo Biotechnology Co., Ltd (Guangzhou, Guangdong, China). To analyse the DEGs between the wild-type, $\Delta h t s H 1, \Delta h t s H 2, \Delta h t s H 3, \Delta h t s H 12, \Delta h t s H 13, \Delta h t s H 23$, and $\Delta h t s H 123$ mutant strains, the gene expression levels were further normalized using the fragments per kilobase of transcript per million (FPKM) mapped reads method to eliminate the influence of different gene lengths and amounts of sequencing data on the calculation of gene expression. The edgeR package (http://www.r-project.org/) was used to determine DEGs across samples with fold changes $\geq 2$ and a false discovery rate-adjusted $P$ ( $q$ value) $<0.05$. DEGs were then subjected to enrichment analysis of GO functions and KEGG pathways, and q values were corrected using $<0.05$ as the threshold.

\section{Quantitative real-time PCR}

Quantitative real-time PCR was carried out according to previous studies ${ }^{41}$. The bacterial cells were collected when the cellular optical density (OD600) reached 1.0 in 10\% TSB. Total RNA was extracted using a TRIzol-based method (Life Technologies, CA, USA). RNA quality control was performed via several steps: (1) the degree of RNA degradation and potential contamination were monitored on $1 \%$ agarose gels; (2) the RNA purity (OD260/OD280, OD260/OD230) was checked using a NanoPhotometer® spectrophotometer (IMPLEN, CA, USA); and (3) the RNA integrity was measured using a Bioanalyser 2100 (Agilent, Santa Clara, CA, USA). The primers used in this assay are listed in Table S2. cDNA was then synthesized from each RNA sample (400 ng) using the TransScript ${ }^{\circledR}$ All-in-One First-Strand cDNA Synthesis SuperMix for qPCR (One-Step gDNA Removal) Kit (TransGen Biotech, Beijing, China) according to the manufacturer's instructions. qRT-PCR was performed using TransStart Top Green qPCR SuperMix (TransGen Biotech) on a QuantStudio TM 6 Flex Real-Time PCR System (Applied Biosystems, Foster City, CA, USA) with the following thermal cycling parameters: denaturation at $94^{\circ} \mathrm{C}$ for $30 \mathrm{~s}$, followed by 40 cycles of $94^{\circ} \mathrm{C}$ for $5 \mathrm{~s}$ and $60^{\circ} \mathrm{C}$ for $34 \mathrm{~s}$. Gene expression analyses were performed using the $2^{-\Delta \Delta C T}$ method with 16S rRNA as the endogenous control, and the expression level in the wild type was set to a value of 1 . The experiments were performed three times, and three replicates were examined in each run.

\section{Pull-down assay}

The assay was performed as described previously ${ }^{24}$. Briefly, the purified proteins were used to perform the pull-down assay in a reaction system comprising $800 \mu \mathrm{L}$ PBS buffer, $5 \mu \mathrm{M}$ (final concentration) MBPRpfG and HtsH1C-Flag-His, HtsH2C-HA-His or HtsH3C-Myc-His proteins, and $50 \mu \mathrm{L}$ Dextrin Sepharose High Performance agarose (Sigma-Aldrich, St. Louis, MO, USA). All samples were incubated at $4^{\circ} \mathrm{C}$ overnight. The agarose was collected by centrifugation and washed 10 times with PBS containing $1 \%$ Triton X-100 to remove non-specifically bound proteins. The MBP-bead-captured proteins were eluted by boiling in $6 \times$ SDS loading dye for $10 \mathrm{~min}$. These samples were subjected to SDS-PAGE and Western blotting. Protein detection involved the use of MBP- (ab49923), Flag- (ab1162), HA- (ab187915), Myc(ab32072), and His- (ab18184) specific antibodies obtained from Abcam, UK.

\section{Phosphorylation analysis through Phos-tag gel}


The purified HtsH1C-Flag-His, HtsH2C-HA-His, or HtsH3C-Myc-His proteins (100 ng) were incubated with CIAP (Solarbio, Beijing, China) at $28^{\circ} \mathrm{C}$ for $60 \mathrm{~min}$ and resolved by $8 \%$ SDS-PAGE prepared with $50 \mu \mathrm{M}$ acrylamide-dependent Phos-tag ligand and $100 \mu \mathrm{M} \mathrm{MnCl}_{2}$ as previously described ${ }^{42}$. Gel electrophoresis was performed with a constant voltage of $80 \mathrm{~V}$ for 3-6 h. Before transfer, the gels were equilibrated in transfer buffer with $5 \mathrm{mM}$ EDTA for 20 min two times, followed by transfer buffer without EDTA for another $20 \mathrm{~min}$. Protein transfer from the $\mathrm{Mn}^{2+}$ phos-tag acrylamide (APExBIO, Houston, USA) gel to the PVDF membrane (Millipore, Massachusetts, USA) was performed for $\sim 24 \mathrm{~h}$ at $80 \mathrm{~V}$ at $4^{\circ} \mathrm{C}$, and then the membrane was analysed by Western blotting using the anti-His antibody.

\section{Bacterial one-hybrid assays}

Bacterial one-hybrid assays were performed as previously described ${ }^{43,44}$. In brief, the bacterial one-hybrid reporter system contains three components: the plasmids pBXcmT and PTRG, which are used to clone the target DNA and to express the target protein, respectively, and the E. coli XL1-Blue MRFQ kan strain, which is the host strain for the propagation of the pBXcmT and pTRG recombinants ${ }^{45}$. In this study, the promoter of the HSAF biosynthesis gene ( $\mathrm{p} / \mathrm{afB}$ ) was cloned into $\mathrm{pBXcmT}$ to generate the recombinant vector $\mathrm{pBXcmT-p/afB}$. Similarly, the coding regions of Le $h t s H 1$, Le $h t s H 2$, and Le $h t s H 3$ were cloned into pTRG to create the final constructs pTRG- $h t s H 1$, pTRG- $h t s H 2$, and pTRG- $h t s H 3$, respectively. The two recombinant vectors were transformed into the XL1-Blue MRF® kan strain. If direct physical binding occurred between $\mathrm{HtsH} 1, \mathrm{HtsH} 2$, or $\mathrm{HtsH} 3$ and plafB, the positive-transformant $E$. colis strain containing both pBXcmT-p/afB and pTRG-HtsHs would grow well on selective medium, that is, minimal medium containing $5 \mathrm{mM}$ 3-amino-1,2,4-triazole, $8 \mu \mathrm{g} / \mathrm{mL}$ streptomycin, $12.5 \mu \mathrm{g} / \mathrm{mL}$ tetracycline, $34 \mu \mathrm{g} / \mathrm{mL}$ chloramphenicol, and $30 \mu \mathrm{g} / \mathrm{mL}$ kanamycin. Furthermore, cotransformants containing pBX-R2031/pTRGR3133 served as a positive control ${ }^{45}$, and cotransformants containing either empty pTRG or pBXcmTplafB were used as negative controls. All cotransformants were spotted onto selective medium, grown at $28^{\circ} \mathrm{C}$ for 3-4 days, and then photographed.

\section{Electrophoretic mobility gel shift assays (EMSAs)}

EMSA was performed as previously described ${ }^{46,47}$. For $\mathrm{HtsH} 1$, $\mathrm{HtsH} 2$, or $\mathrm{HtsH} 3$ gel shift assays, we used DNA fragments that included plafB as a probe. The probe DNA (50 ng) was mixed with protein in a $20 \mu \mathrm{L}$ reaction mixture containing $10 \mathrm{mM}$ Tris $-\mathrm{HCl}(\mathrm{pH} 7.5), 50 \mathrm{mM} \mathrm{KCl}, 1 \mathrm{mM}$ dithiothreitol, and $0.4 \%$ glycerol. After incubation for $30 \mathrm{~min}$ at $28^{\circ} \mathrm{C}$, samples were electrophoresed on a $5 \%$ nondenaturing acrylamide gel in $0.5 \times$ TBE buffer at $4^{\circ} \mathrm{C}$. The gel was soaked in 10,000-fold-diluted SYBR Green I nucleic acid dye (Sangon Biotech, Shanghai, China), and the DNA was visualized at $300 \mathrm{~nm}$.

\section{HSAF extraction and quantification}

HSAF was extracted from $50 \mathrm{~mL}$ L. enzymogenes cultures grown in $10 \% \mathrm{TSB}$ for $48 \mathrm{~h}$ at $28^{\circ} \mathrm{C}$ with shaking (at $180 \mathrm{rpm}$ ). HSAF was detected via HPLC and quantified per unit of OD600 as described 
previously $6,24,48$. Three biological replicates were used, and each was examined with three technical replicates.

\section{Statistical analyses}

The experimental datasets were subjected to analyses of variance using GraphPad Prism 7.0. The significance of the treatment effects was determined by the $\mathrm{F}$ value $(P=0.05)$. If a significant $\mathrm{F}$ value was obtained, separation of means was accomplished by Fisher's protected least significant difference at $P \leq 0.05$.

\section{Declarations}

\section{Supporting information}

Additional Supporting Information may be found in the online version of this article at the publisher's web-site:

\section{Author contributions}

K.L. and F.L. conceived and designed the experiments. K.L., G.X., B.W., and G.W. performed the experiments. K.L. analysed the data and prepared the figures. K.L. and F.L. wrote the manuscript draft. F.L. revised the manuscript. All authors read and approved the final manuscript.

\section{Acknowledgments}

The authors thank Jialei Wang, Ning Wang and Cunfa Xu at the Central Laboratory of Jiangsu Academy of Agricultural Sciences for LC-MS/MS and SPR technical support. This study was funded by the National Natural Science Foundation of China (31872018), the Natural Science Foundation of Jiangsu Province (BK20190266), and the Earmarked Fund for China Agriculture Research System (CARS-28).

\section{Conflict of interest}

The authors declare no competing financial interests.

\section{Data availability statement}

The data that support the findings of this study are openly available in GenBank at https://www.ncbi.nlm.nih.gov/nuccore/, accession numbers RCTY01000033 (Lysobacter enzymogenes strain OH11 scffold34, whole genome shotgun sequence; Le4727/Le RpfG, locus tag = D9T17_13845), RCTY01000055 (Lysobacter enzymogenes strain OH11 scffold56, whole genome shotgun sequence, Le3071/Le HtsH1, locus tag = D9T17_21400) ), RCTY01000054 (Lysobacter enzymogenes strain OH11 scffold55, whole genome shotgun sequence, Le3072/Le HtsH2, locus tag = D9T17_21390), RCTY01000054 (Lysobacter enzymogenes strain OH11 scffold55, whole genome shotgun sequence, Le3073/Le HtsH3, locus tag = D9T17_21385). 


\section{References}

1 McCarthy, R. R., Yu, M., Eilers, K., Wang, Y. C., Lai, E. M. \& Filloux, A. Cyclic di-GMP inactivates T6SS and T4SS activity in Agrobacterium tumefaciens. Mol Microbio/ 112, 632-648 (2019).

2 Deng, Y., Wu, J., Yin, W., Li, P., Zhou, J., Chen, S., He, F., Cai, J. \& Zhang, L. H. Diffusible signal factor family signals provide a fitness advantage to Xanthomonas campestris pv. campestris in interspecies competition. Environ Microbio/ 18, 1534-1545 (2016).

3 Boon, C., Deng, Y., Wang, L. H., He, Y., Xu, J. L., Fan, Y., Pan, S. Q. \& Zhang, L. H. A novel DSF-like signal from Burkholderia cenocepacia interferes with Candida albicans morphological transition. ISME J 2, 2736 (2008).

4 Deng, Y., Wu, J., Eberl, L. \& Zhang, L. H. Structural and functional characterization of diffusible signal factor family quorum-sensing signals produced by members of the Burkholderia cepacia complex. Appl Environ Microbiol 76, 4675-4683 (2010).

5 Deng, Y., Wu, J., Tao, F. \& Zhang, L. H. Listening to a new language: DSF-based quorum sensing in Gram-negative bacteria. Chem Rev 111, 160-173 (2011).

6 Qian, G., Wang, Y., Liu, Y., Xu, F., He, Y. W., Du, L., Venturi, V., Fan, J., Hu, B. \& Liu, F. Lysobacter enzymogenes uses two distinct cell-cell signaling systems for differential regulation of secondarymetabolite biosynthesis and colony morphology. Appl Environ Microbio/ 79, 6604-6616 (2013).

7 Barber, C. E., Tang, J. L., Feng, J. X., Pan, M. Q., Wilson, T. J., Slater, H., Dow, J. M., Williams, P. \& Daniels, M. J. A novel regulatory system required for pathogenicity of Xanthomonas campestris is mediated by a small diffusible signal molecule. Mol Microbiol 24, 555-566 (1997).

8 Chatterjee, S. \& Sonti, R. V. rpfF mutants of Xanthomonas oryzaepv. oryzae are deficient for virulence and growth under low iron conditions. Mol Plant Microbe Interact 15, 463-471 (2002).

9 He, Y. W., Wang, C., Zhou, L., Song, H., Dow, J. M. \& Zhang, L. H. Dual signaling functions of the hybrid sensor kinase RpfC of Xanthomonas campestris involve either phosphorelay or receiver domain-protein interaction. J Biol Chem 281, 33414-33421 (2006).

10 Ryan, R. P., McCarthy, Y., Andrade, M., Farah, C. S., Armitage, J. P. \& Dow, J. M. Cell-cell signaldependent dynamic interactions between HD-GYP and GGDEF domain proteins mediate virulence in Xanthomonas campestris. Proc Natl Acad Sci U S A 107, 5989-5994 (2010).

11 Andrade, M. O., Alegria, M. C., Guzzo, C. R., Docena, C., Rosa, M. C., Ramos, C. H. \& Farah, C. S. The HDGYP domain of RpfG mediates a direct linkage between the Rpf quorum-sensing pathway and a subset of diguanylate cyclase proteins in the phytopathogen Xanthomonas axonopodis pv citri. Mol Microbiol 62, 537-551 (2006). 
12 Bellini, D., Caly, D. L., McCarthy, Y., Bumann, M., An, S. Q., Dow, J. M., Ryan, R. P. \& Walsh, M. A. Crystal structure of an HD-GYP domain cyclic-di-GMP phosphodiesterase reveals an enzyme with a novel trinuclear catalytic iron centre. Mol Microbio/ 91, 26-38 (2014).

13 He, Y. W., Ng, A. Y., Xu, M., Lin, K., Wang, L. H., Dong, Y. H. \& Zhang, L. H. Xanthomonas campestris cellcell communication involves a putative nucleotide receptor protein Clp and a hierarchical signalling network. Mol Microbiol 64, 281-292 (2007).

14 Tao, F., He, Y. W., Wu, D. H., Swarup, S. \& Zhang, L. H. The cyclic nucleotide monophosphate domain of Xanthomonas campestris global regulator Clp defines a new class of cyclic di-GMP effectors. $J$ Bacteriol 192, 1020-1029 (2010).

15 Zhou, L., Zhang, L. H., Camara, M. \& He, Y. W. The DSF family of quorum sensing signals: diversity, biosynthesis, and turnover. Trends Microbiol 25, 293-303 (2017).

16 Zhao, Y., Cheng, C., Jiang, T., Xu, H., Chen, Y., Ma, Z., Qian, G. \& Liu, F. Control of wheat Fusarium head blight by heat-stable antifungal factor (HSAF) from Lysobacter enzymogenes. Plant Dis 103, 1286-1292 (2019).

17 Zhao, Y., Qian, G., Chen, Y., Du, L. \& Liu, F. Transcriptional and antagonistic responses of biocontrol strain Lysobacter enzymogenes $\mathrm{OH} 11$ to the plant pathogenic oomycete Pythium aphanidermatum. Front Microbiol 8, 1025 (2017).

18 Qian, G. L., Hu, B. S., Jiang, Y. H. \& Liu, F. Q. Identification and characterization of Lysobacter enzymogenes as a biological control agent against some fungal pathogens. Agricultural Sciences in China 8, 68-75 (2009).

19 Odhiambo, B. O., Xu, G., Qian, G. \& Liu, F. Evidence of an unidentified extracellular heat-stable factor produced by Lysobacter enzymogenes (OH11) that degrade Fusarium graminearum PH1 hyphae. Curr Microbiol 74, 437-448 (2017).

20 Lou, L., Qian, G., Xie, Y., Hang, J., Chen, H., Zaleta-Rivera, K., Li, Y., Shen, Y., Dussault, P. H., Liu, F. \& Du, L. Biosynthesis of HSAF, a tetramic acid-containing macrolactam from Lysobacter enzymogenes. J Am Chem Soc 133, 643-645 (2011).

21 Yu, F., Zaleta-Rivera, K., Zhu, X., Huffman, J., Millet, J. C., Harris, S. D., Yuen, G., Li, X. C. \& Du, L. Structure and biosynthesis of heat-stable antifungal factor (HSAF), a broad-spectrum antimycotic with a novel mode of action. Antimicrob Agents Chemother 51, 64-72 (2007).

22 Li, S., Du, L., Yuen, G. \& Harris, S. D. Distinct ceramide synthases regulate polarized growth in the filamentous fungus Aspergillus nidulans. Mol Biol Cell 17, 1218-1227 (2006).

23 Li, Y., Wang, H., Liu, Y., Jiao, Y., Li, S., Shen, Y. \& Du, L. Biosynthesis of the polycyclic system in the antifungal HSAF and analogues from Lysobacter enzymogenes. Angew Chem Int Ed Eng/ 57, 6221-6225 
(2018).

24 Xu, G., Han, S., Huo, C., Chin, K. H., Chou, S. H., Gomelsky, M., Qian, G. \& Liu, F. Signaling specificity in the c-di-GMP-dependent network regulating antibiotic synthesis in Lysobacter. Nucleic Acids Res 46, 9276-9288 (2018).

25 Han, Y., Wang, Y., Tombosa, S., Wright, S., Huffman, J., Yuen, G., Qian, G., Liu, F., Shen, Y. \& Du, L. Identification of a small molecule signaling factor that regulates the biosynthesis of the antifungal polycyclic tetramate macrolactam HSAF in Lysobacter enzymogenes. Appl Microbiol Biotechno/ 99, 801811 (2015).

26 Galperin, M. Y., Natale, D. A., Aravind, L. \& Koonin, E. V. A specialized version of the HD hydrolase domain implicated in signal transduction. J Mol Microbiol Biotechnol 1, 303-305 (1999).

27 Galperin, M. Y., Nikolskaya, A. N. \& Koonin, E. V. Novel domains of the prokaryotic two-component signal transduction systems. FEMS Microbiol Lett 203, 11-21 (2001).

28 Borland, S., Prigent-Combaret, C. \& Wisniewski-Dye, F. Bacterial hybrid histidine kinases in plantbacteria interactions. Microbiology 162, 1715-1734 (2016).

29 Cui, Y., Tu, R., Wu, L., Hong, Y. \& Chen, S. A hybrid two-component system protein from Azospirillum brasilense Sp7 was involved in chemotaxis. Microbiol Res 166, 458-467 (2011).

30 Parkinson, J. S., Hazelbauer, G. L. \& Falke, J. J. Signaling and sensory adaptation in Escherichia coli chemoreceptors: 2015 update. Trends Microbio/ 23, 257-266 (2015).

31 Chambonnier, G., Roux, L., Redelberger, D., Fadel, F., Filloux, A., Sivaneson, M., de Bentzmann, S. \& Bordi, $C$. The hybrid histidine kinase LadS forms a multicomponent signal transduction system with the GacS/GacA two-component system in Pseudomonas aeruginosa. PLoS Genet 12, e1006032 (2016).

32 Deng, C. Y., Zhang, H., Wu, Y., Ding, L. L., Pan, Y., Sun, S. T., Li, Y. J., Wang, L. \& Qian, W. Proteolysis of histidine kinase VgrS inhibits its autophosphorylation and promotes osmostress resistance in Xanthomonas campestris. Nat Commun 9, 4791 (2018).

33 Cheng, S. T., Wang, F. F. \& Qian, W. Cyclic-di-GMP binds to histidine kinase RavS to control RavS-RavR phosphotransfer and regulates the bacterial lifestyle transition between virulence and swimming. PLOS Pathog 15, e1007952 (2019).

34 Wang, F. F., Cheng, S. T., Wu, Y., Ren, B. Z. \& Qian, W. A bacterial receptor PcrK senses the plant hormone cytokinin to promote adaptation to oxidative stress. Cell Rep 21, 2940-2951 (2017).

$35 \mathrm{Li}$, K., Hou, R., Xu, H., Wu, G., Qian, G., Wang, H. \& Liu, F. Two functional fatty acyl coenzyme A ligases affect free fatty acid metabolism to block biosynthesis of an antifungal antibiotic in Lysobacter enzymogenes. Appl Environ Microbiol 86, e00309-00320 (2020). 
36 Li, K.-H., Yu, Y.-H., Dong, H.-J., Zhang, W.-B., Ma, J.-C. \& Wang, H.-H. Biological functions of ilvC in branched-chain fatty acid synthesis and diffusible signal factor family production in Xanthomonas campestris. Front Microbio/ 8, 2486 (2017).

37 Li, K., Wu, G., Liao, Y., Zeng, Q., Wang, H. \& Liu, F. RpoN1 and RpoN2 play different regulatory roles in virulence traits, flagellar biosynthesis, and basal metabolism in Xanthomonas campestris. Mol Plant Pathol 21, 907-922 (2020).

38 Kovach, M. E., Elzer, P. H., Hill, D. S., Robertson, G. T., Farris, M. A., Roop, R. M., 2nd \& Peterson, K. M. Four new derivatives of the broad-host-range cloning vector pBBR1MCS, carrying different antibioticresistance cassettes. Gene 166, 175-176 (1995).

39 Yang, C., Cui, C., Ye, Q., Kan, J., Fu, S., Song, S., Huang, Y., He, F., Zhang, L. H., Jia, Y., Gao, Y. G., Harwood, C. S. \& Deng, Y. Burkholderia cenocepacia integrates cis-2-dodecenoic acid and cyclic dimeric guanosine monophosphate signals to control virulence. Proc Natl Acad Sci U S A 114, 13006-13011 (2017).

40 Zhou, M., Shen, D., Xu, G., Liu, F. \& Qian, G. ChpA controls twitching motility and broadly affects gene expression in the biological control agent Lysobacter enzymogenes. Curr Microbiol 74, 566-574 (2017).

41 Cui, C., Yang, C., Song, S., Fu, S., Sun, X., Yang, L., He, F., Zhang, L. H., Zhang, Y. \& Deng, Y. A novel twocomponent system modulates quorum sensing and pathogenicity in Burkholderia cenocepacia. Mol Microbiol 108, 32-44 (2018).

42 Yin, Z., Feng, W., Chen, C., Xu, J., Li, Y., Yang, L., Wang, J., Liu, X., Wang, W., Gao, C., Zhang, H., Zheng, X., Wang, P. \& Zhang, Z. Shedding light on autophagy coordinating with cell wall integrity signaling to govern pathogenicity of Magnaporthe oryzae. Autophagy 16, 900-916 (2020).

43 Xu, H., Chen, H., Shen, Y., Du, L., Chou, S. H., Liu, H., Qian, G. \& Liu, F. Direct regulation of extracellular chitinase production by the transcription factor LeClp in Lysobacter enzymogenes $\mathrm{OH} 11$. Phytopathology 106, 971-977 (2016).

44 Wang, B., Wu, G., Zhang, Y., Qian, G. \& Liu, F. Dissecting the virulence-related functionality and cellular transcription mechanism of a conserved hypothetical protein in Xanthomonas oryzae pv. oryzae. Mol Plant Pathol 19, 1859-1872 (2018).

45 Guo, M., Feng, H., Zhang, J., Wang, W., Wang, Y., Li, Y., Gao, C., Chen, H., Feng, Y. \& He, Z. G. Dissecting transcription regulatory pathways through a new bacterial one-hybrid reporter system. Genome Res 19, 1301-1308 (2009).

46 Hirakawa, H., Hirakawa, Y., Greenberg, E. P. \& Harwood, C. S. BadR and BadM Proteins Transcriptionally Regulate Two Operons Needed for anaerobic benzoate degradation by Rhodopseudomonas palustris. Appl Environ Microbio/ 81, 4253-4262 (2015). 
47 Shao, X., Zhang, X., Zhang, Y., Zhu, M., Yang, P., Yuan, J., Xie, Y., Zhou, T., Wang, W., Chen, S., Liang, H. \& Deng, $X$. RpoN-dependent direct regulation of quorum sensing and the type $\mathrm{VI}$ secretion system in Pseudomonas aeruginosa PA01. J Bacterio/ 200, e00205-00218 (2018).

48 Wang, Y., Zhao, Y., Zhang, J., Zhao, Y., Shen, Y., Su, Z., Xu, G., Du, L., Huffman, J. M., Venturi, V., Qian, G. \& Liu, F. Transcriptomic analysis reveals new regulatory roles of Clp signaling in secondary metabolite biosynthesis and surface motility in Lysobacter enzymogenes OH11. Appl Microbiol Biotechno/ 98, 90099020 (2014).

\section{Figures}


A

C
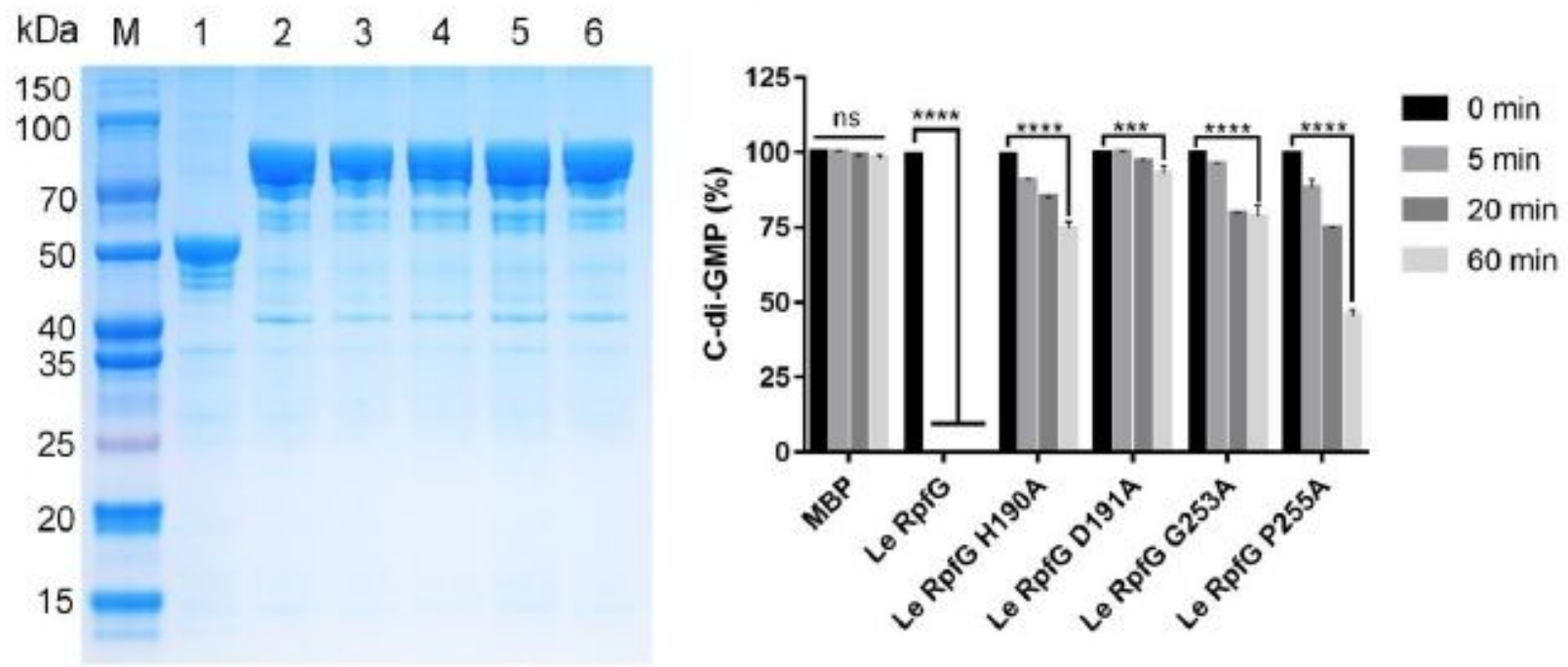

B

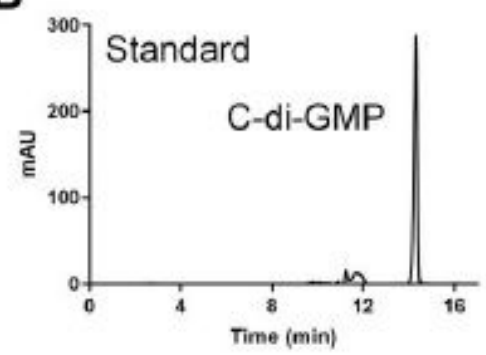

$20 \mathrm{~min}$
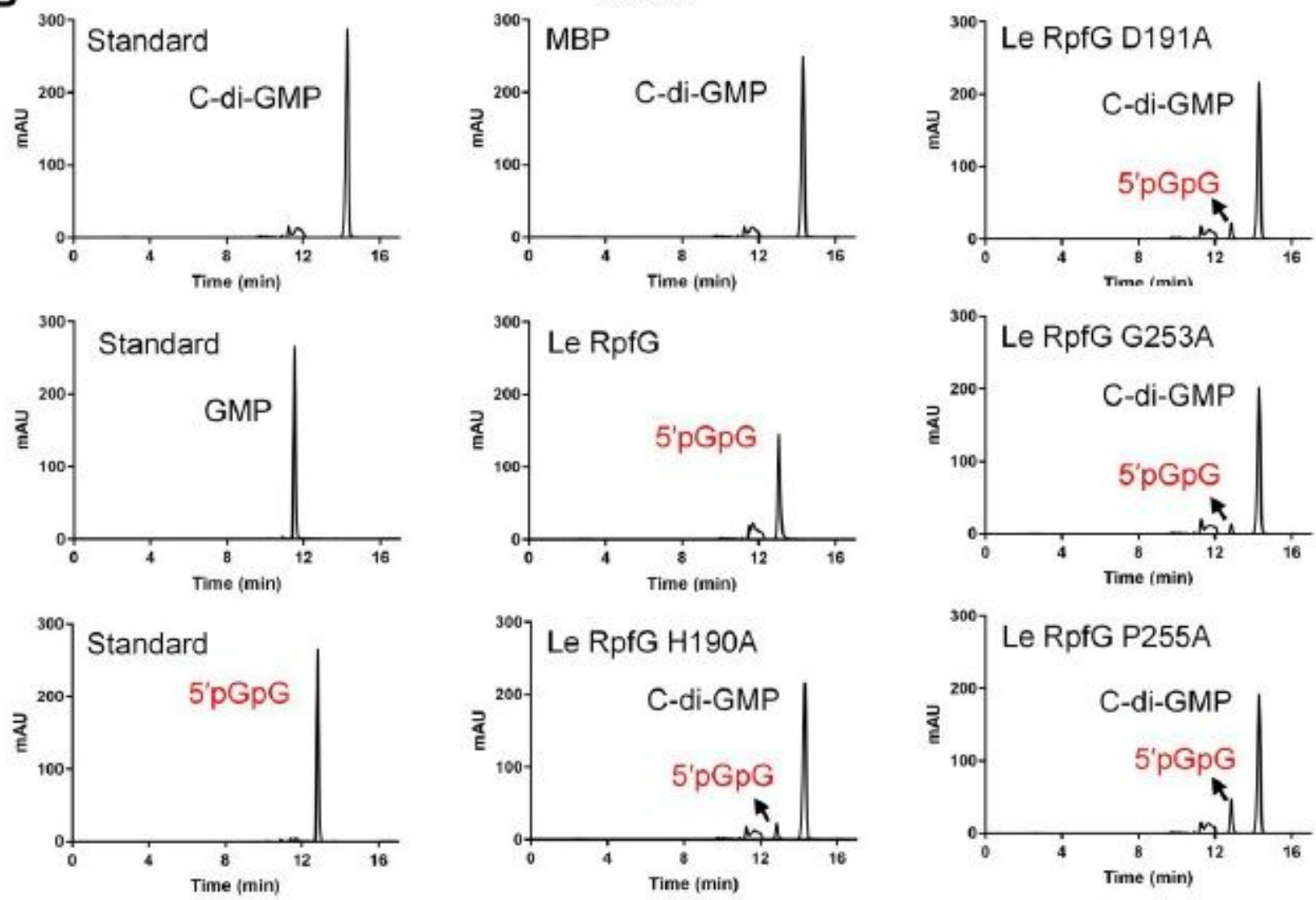

\section{Figure 1}

RpfG is a PDE enzyme. (A) The purified protein was analysed by $12 \%$ SDS-PAGE. Lane M, molecular mass markers; lane 1, MBP protein; lane 2, RpfG-MBP protein; lane 3, RpfG-MBP H190A protein; lane 4, RpfG-MBP D191A protein; lane 5, RpfG-MBP G253A protein; lane 6, RpfG-MBP P255A protein. (B) The purified protein has enzymatic activity against c-di-GMP. HPLC analysis of aliquots of reaction mixtures boiled immediately after addition of the enzyme and after 20 min of incubation shows the degradation of 
c-di-GMP to a compound with the same mobility as the 5'pGpG standard. (C) The purified RpfG protein has PDE enzymatic activity. For convenience of comparison, the peak of c-di-GMP in the RpfG solution at 0 min was defined as $100 \%$ and used to normalize the c-di-GMP level ratios at different time points. Error bars, means \pm standard deviations $(\mathrm{n}=3) . * * * \mathrm{P}<0.001, * * * * \mathrm{P}<0.0001$, assessed by one-way ANOVA. All experiments were repeated three times with similar results.
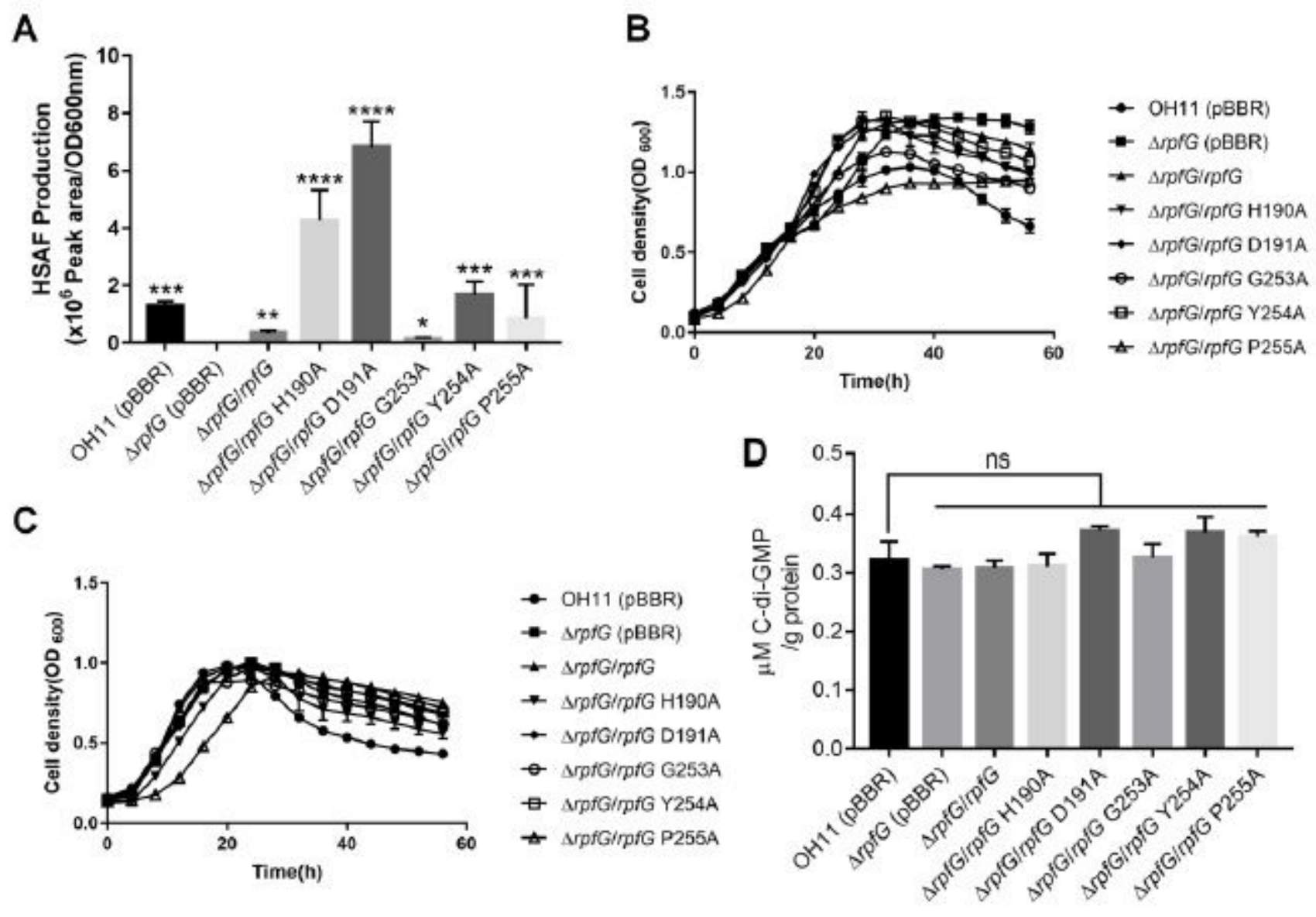

\section{Figure 2}

RpfG-mediated regulation of HSAF production does not depend on its PDE activity. (A) Quantification of HSAF produced by the rpfG mutant strain and strains complemented with $\mathrm{rpfG}$ or the rpfG site-directed mutant genes grown in 10\% TSB medium. (B) Growth curves of the rpfG mutant strain and strains complemented with rpfG or the rpfG site-directed mutant genes in rich LB medium. (C) Growth curves of the rpfG mutant strain and strains complemented with the rpfG or rpfG site-directed mutant genes in $10 \%$ TSB medium. (D) Intracellular c-di-GMP concentrations in the wild type, rpfG mutant and strains complemented with $\mathrm{rpfG}$ or the $\mathrm{rpfG}$ site-directed mutant genes. Error bars, means \pm standard deviations $(\mathrm{n}=3) . * \mathrm{P}<0.05, * * \mathrm{P}<0.01, * * * \mathrm{P}<0.001, * * * * \mathrm{P}<0.0001$, assessed by one-way ANOVA. All experiments were repeated three times with similar results. 


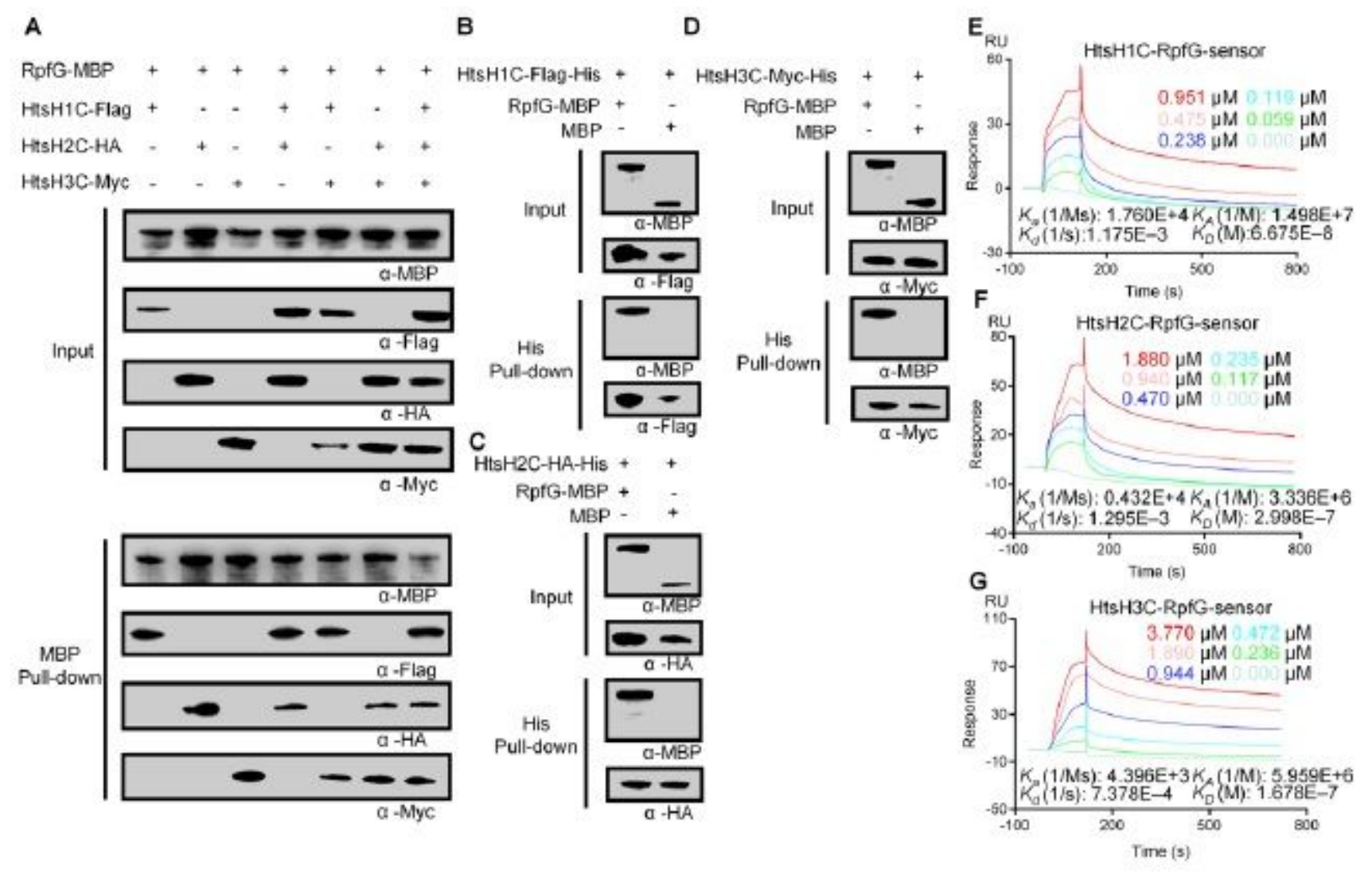

\section{Figure 3}

RpfG interaction with $\mathrm{HtsH} 1, \mathrm{HtsH}$, and $\mathrm{HtsH}$. (A) An MBP pull-down assay confirming interactions between RpfG-MBP and the cytoplasmic fragment of HtsH1, HtsH2, and HtsH3 (HtsH1C-Flag-His, $\mathrm{HtsH} 2 \mathrm{C}-\mathrm{HA}-\mathrm{His}$ and $\mathrm{HtsH} 3 \mathrm{C}-\mathrm{Myc}-\mathrm{His}$, respectively). The pull-down assay was carried out using anti-MBP antibody. Western blotting was performed using anti-MBP, anti-Flag, anti-HA, and anti-Myc antibodies. (B) A His pull-down assay confirming interactions between the cytoplasmic fragment of $\mathrm{HtsH} 1$ (HtsH1C-FlagHis) and RpfG-MBP. The pull-down assay was carried out using Ni-nitrilotriacetic acid (NTA) agarose. Western blotting was performed using anti-Flag and anti-MBP antibodies. (C) A His pull-down assay confirming interactions between the cytoplasmic fragment of $\mathrm{HtsH} 2(\mathrm{HtsH} 2 \mathrm{C}-\mathrm{HA}-\mathrm{His})$ and RpfG-MBP. The pull-down assay was carried out using Ni-NTA agarose. Western blotting was performed using anti-HA and anti-MBP antibodies. (D) A His pull-down assay confirming interactions between the cytoplasmic fragment of $\mathrm{HtsH} 3$ (HtsH3C-Myc-His) and RpfG-MBP. The pull-down assay was carried out using Ni-NTA agarose. Western blotting was performed using anti-Myc and anti-MBP antibodies. (E) SPR showing that HtsH1C-Flag-His forms a complex with RpfG-MBP with KD $=0.06675 \mu \mathrm{M}$. (F) SPR showing that HtsH2CHA-His forms a complex with RpfG-MBP with KD $=0.2998 \mu \mathrm{M}$. (G) SPR showing that HtsH3C-Myc-His forms a complex with RpfG-MBP with $\mathrm{KD}=0.1678 \mu \mathrm{M}$. 


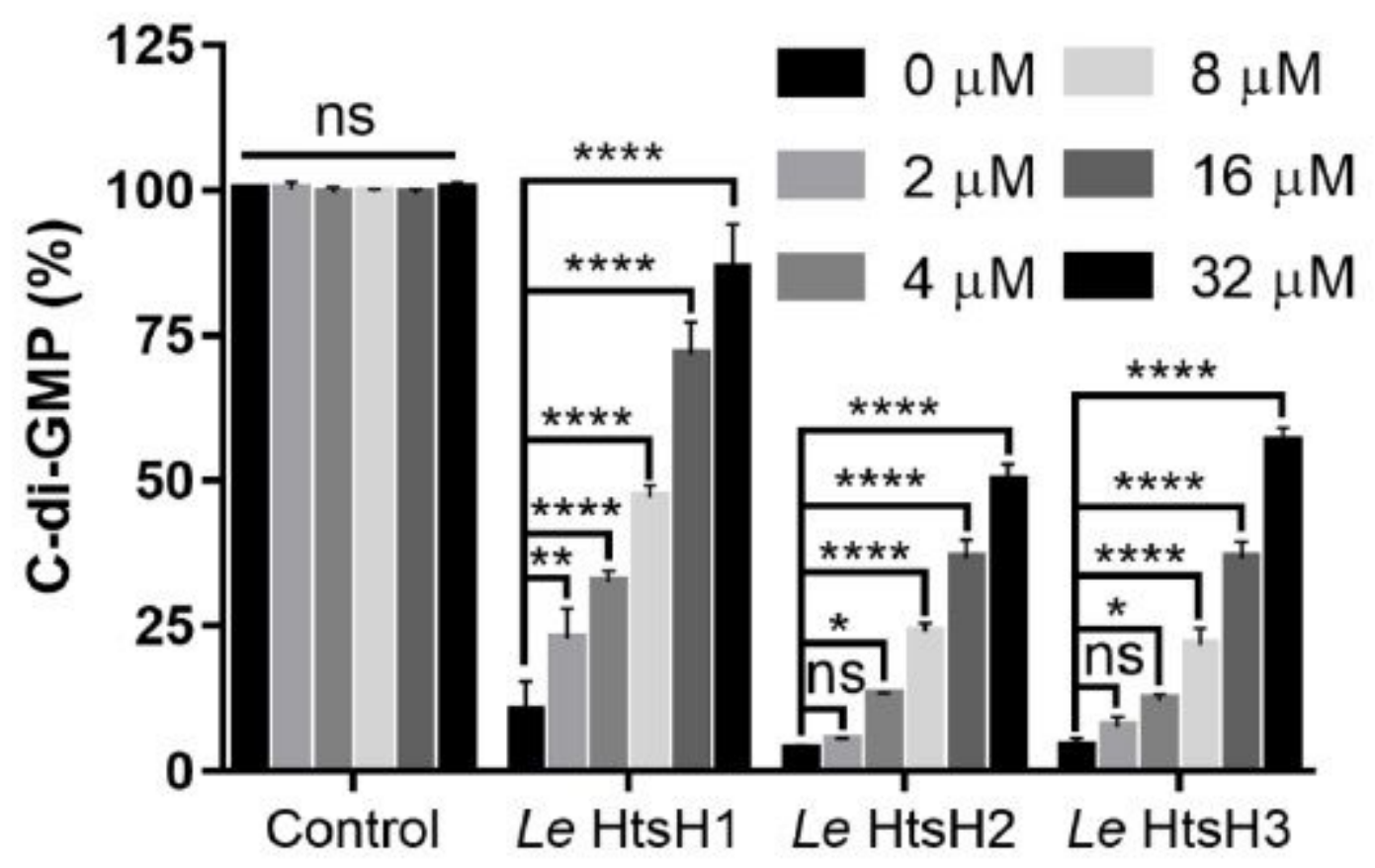

Figure 4

Impact of $\mathrm{HtsH} 1, \mathrm{HtsH} 2$, and $\mathrm{HtsH} 3$ on RpfG enzyme activity. The addition of $\mathrm{HtsH} 1 \mathrm{C}$-Flag-His, $\mathrm{HtsH} 2 \mathrm{C}$ $\mathrm{HA}-\mathrm{His}$, and HtsH3C-Myc-His proteins to an RpfG-MBP protein solution decreased its c-di-GMP phosphodiesterase activity. For convenience of comparison, the peak of c-di-GMP in the MBP solution was defined as $100 \%$ and used to normalize the c-di-GMP level ratios at $20 \mathrm{~min}$. 
A

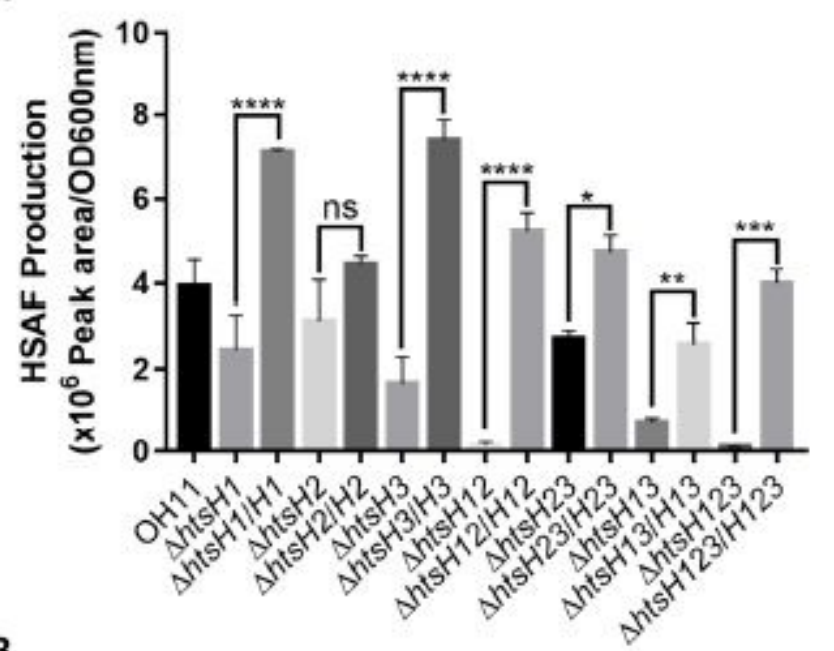

B

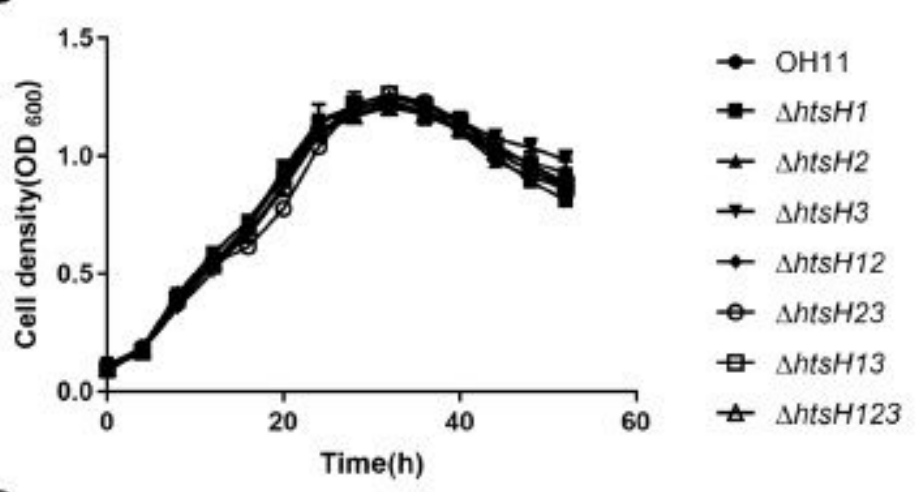

C
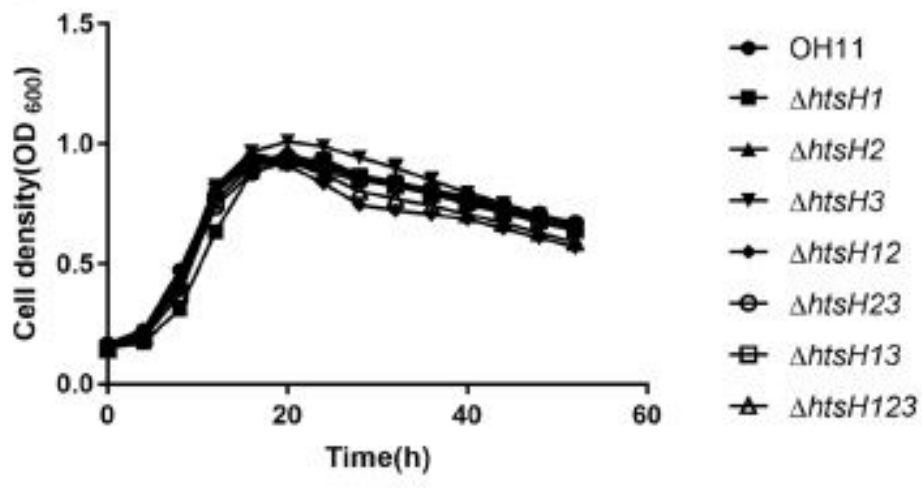

Figure 5

Deletion of htsH1, htsH2, and htsH3 resulted in decreased HSAF production. (A) Quantification of the HSAF produced by the hts $\mathrm{H} 1$, htsH2 and htsH3 mutant strains and strains complemented with the htsH1, hts 2 , and hts $\mathrm{H} 3$ genes grown in $10 \%$ TSB medium. (B) Growth curves of the hts $\mathrm{H} 1$, hts $\mathrm{H} 2$, and htsH3 mutant strains and strains complemented with the hts $\mathrm{H} 1$, hts $\mathrm{H} 2$, and hts 3 genes in LB-rich medium. (C) Growth curves of the hts $\mathrm{H} 1$, hts $\mathrm{H} 2$, and hts $\mathrm{H} 3$ mutant strains and strains complemented with the hts $\mathrm{H} 1$, hts 2 , and hts 3 genes in 10\% TSB medium. Error bars, means \pm standard deviations $(\mathrm{n}=3) . * \mathrm{P}<0.05$, $* * \mathrm{P}<0.01, * * * \mathrm{P}<0.001, * * * * \mathrm{P}<0.0001$, assessed by one-way ANOVA. All experiments were repeated three times with similar results. 


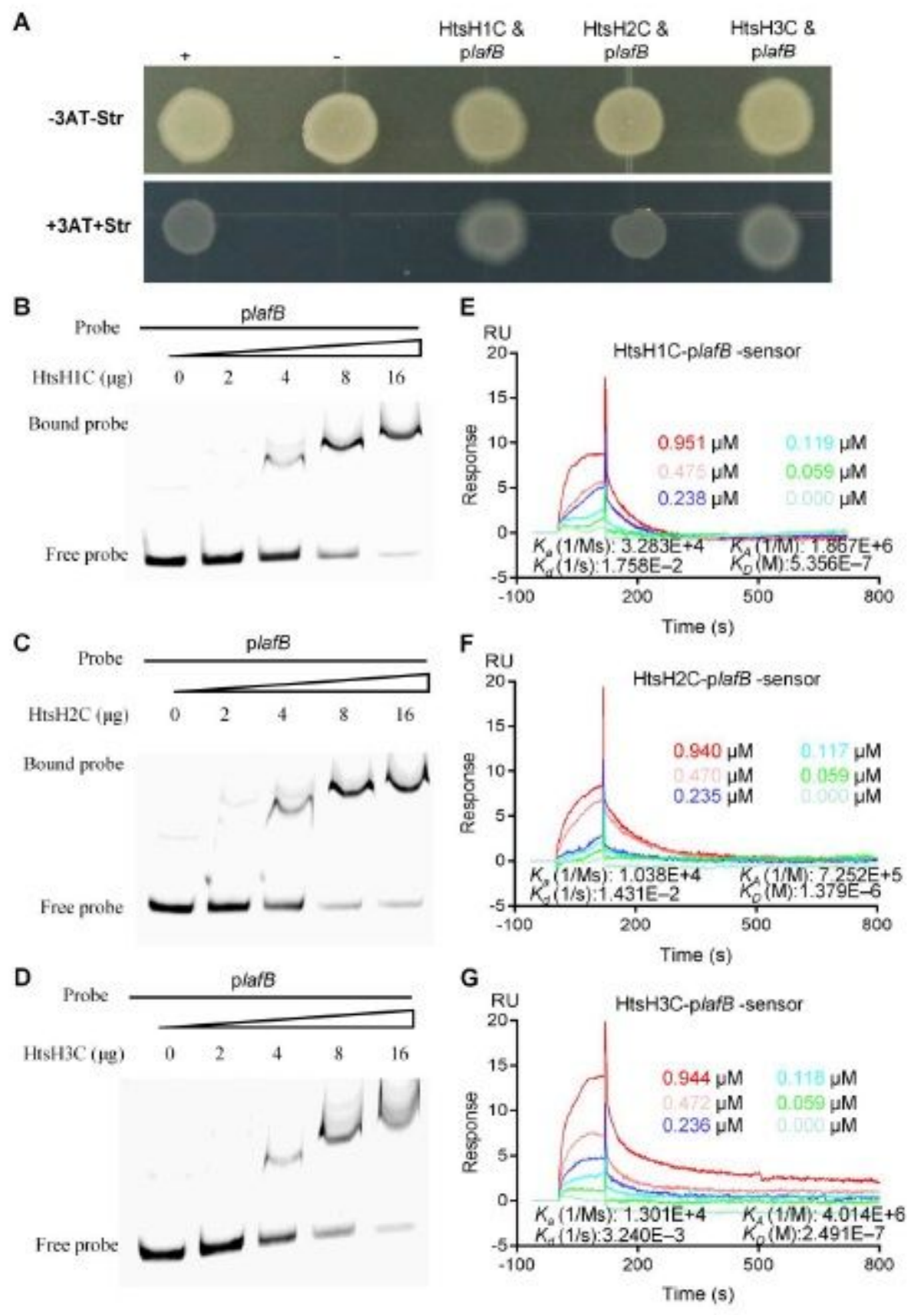

\section{Figure 6}

$\mathrm{HtsH} 1, \mathrm{HtsH} 2$, and $\mathrm{HtsH} 3$ directly bound the promoter of the HSAF biosynthesis gene (plafB). (A) Direct physical interaction between $\mathrm{HtsH} 1, \mathrm{HtsH}$, and $\mathrm{HtsH} 3$ and the lafB promoter region was detected in $\mathrm{E}$. coli. Experiments were performed according to the procedures described in the Materials and Methods section. +, cotransformant containing pBX-R2031 and pTRG-R3133, used as a positive control; -, cotransformant containing pBXcmT and the empty PTRG, used as a negative control; $\mathrm{HtsH} 1 \mathrm{C}$ \& plafB, cotransformant harbouring pTRG-HtsH1C and pBXcmT-plafB; HtsH2C \& plafB, cotransformant harbouring pTRG-HtsH2C and pBXcmT-plafB; HtsH3C \& plafB, cotransformant harbouring pTRG-HtsH3C and pBXcmT-plafB. -3AT-Str, plate with no selective medium (3AT, 3-amino-1,2,4-triazole and Str, streptomycin) and +3AT+Str, plate with M9-based selective medium (B-D) Gel shift assay showing that 
$\mathrm{HtsH} 1, \mathrm{HtsH} 2$, and $\mathrm{HtsH}$ directly regulate an $\mathrm{HSAF}$ biosynthesis gene. $\mathrm{HtsH} 1 \mathrm{C}-\mathrm{Flag}-\mathrm{His}$, $\mathrm{HtsH} 2 \mathrm{C}-\mathrm{HA}-\mathrm{His}$, or HtsH3C-Myc-His protein $(0,1,2,4$ or $8 \mu \mathrm{g})$ was added to reaction mixtures containing $50 \mathrm{ng}$ of probe DNA, and the reaction mixtures were separated on polyacrylamide gels. (E) SPR showing that HtsH1CFlag-His forms a complex with plafB with $\mathrm{KD}=0.5356 \mu \mathrm{M}$. (F) SPR showing that HtsH2C-HA-His forms a complex with plafB with $\mathrm{KD}=1.379 \mu \mathrm{M}$. (G) SPR showing that HtsH3C-Myc-His forms a complex with plafB with $\mathrm{KD}=0.2491 \mu \mathrm{M}$.

A

$$
\begin{aligned}
& \text { HtsH1C }(\mu \mathrm{g}) \\
& \text { CIAP }(\mu \mathrm{g}) \\
& \text { Mn²+-Phos-tag } \\
& \text { SDS-PAGE }
\end{aligned}
$$

B

$$
\begin{array}{rrr}
\mathrm{HtsH} 2 \mathrm{C}(\mu \mathrm{g}) & 4 & 4 \\
\mathrm{CIAP}(\mu \mathrm{g}) & 0 & 0.8
\end{array}
$$

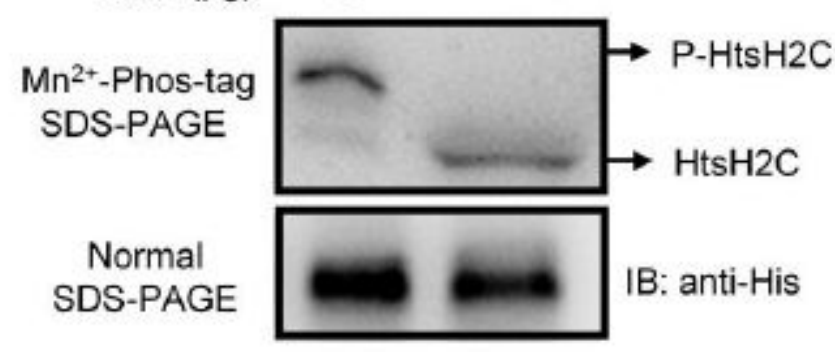

C

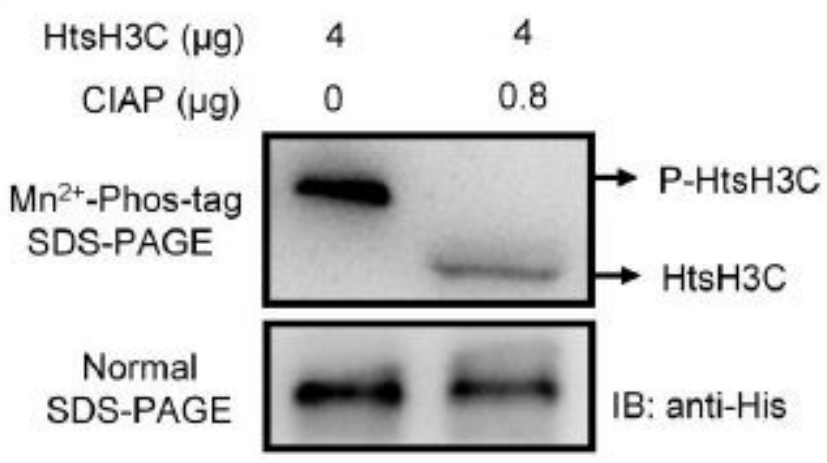

D

$\begin{array}{rccccc}\mathrm{HtsH} 1 \mathrm{C}(\mu \mathrm{g}) & 4 & 4 & 4 & 4 & 4 \\ \mathrm{CIAP}(\mu \mathrm{g}) & 0.1 & 0.2 & 0.4 & 0.8 & 1.6\end{array}$

Bound probe

Free probe

E

$\begin{array}{rccccc}\mathrm{HtsH} 2 \mathrm{C}(\mu \mathrm{g}) & 4 & 4 & 4 & 4 & 4 \\ \mathrm{CIAP}(\mu \mathrm{g}) & 0.1 & 0.2 & 0.4 & 0.8 & 1.6\end{array}$

Bound probe

Free probe

$\mathbf{F}$

$\begin{array}{rccccc}\mathrm{HtsH} 3 \mathrm{C}(\mu \mathrm{g}) & 4 & 4 & 4 & 4 & 4 \\ \mathrm{CIAP}(\mu \mathrm{g}) & 0.1 & 0.2 & 0.4 & 0.8 & 1.6\end{array}$

Bound probe

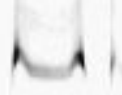

Free probe

Figure 7

$\mathrm{HtsH} 1, \mathrm{HtsH} 2$, and $\mathrm{HtsH} 3$ directly target plafB depending on their PDE activity. (A-C) Phosphorylation analysis of HtsH1C-Flag-His, HtsH2C-HA-His, or HtsH3C-Myc-His with calf intestine alkaline phosphatase (CIAP) at concentrations ranging from $0.1 \mu \mathrm{g}$ to $1.6 \mu \mathrm{g}$ in the reaction mixtures $\left(20 \mu \mathrm{L}, 28^{\circ} \mathrm{C}, 60 \mathrm{~min}\right)$ 
using Mn2+-Phos-tag SDS-PAGE. (D-F) Gel shift assay showing that HtsH1C-Flag-His, HtsH2C-HA-His, or $\mathrm{HtsH} 3 \mathrm{C}-\mathrm{Myc}$-His does not directly target plafB with calf intestine alkaline phosphatase (CIAP) at concentrations ranging from $0.1 \mu \mathrm{g}$ to $1.6 \mu \mathrm{g}$ in the reaction mixtures $\left(20 \mu \mathrm{L}, 28^{\circ} \mathrm{C}, 60 \mathrm{~min}\right)$. $\mathrm{HtsHs}(0,1,2$, 4 or $8 \mu \mathrm{g}$ ) were added to reaction mixtures containing $50 \mathrm{ng}$ of probe DNA, and the reaction mixtures were separated on polyacrylamide gels.

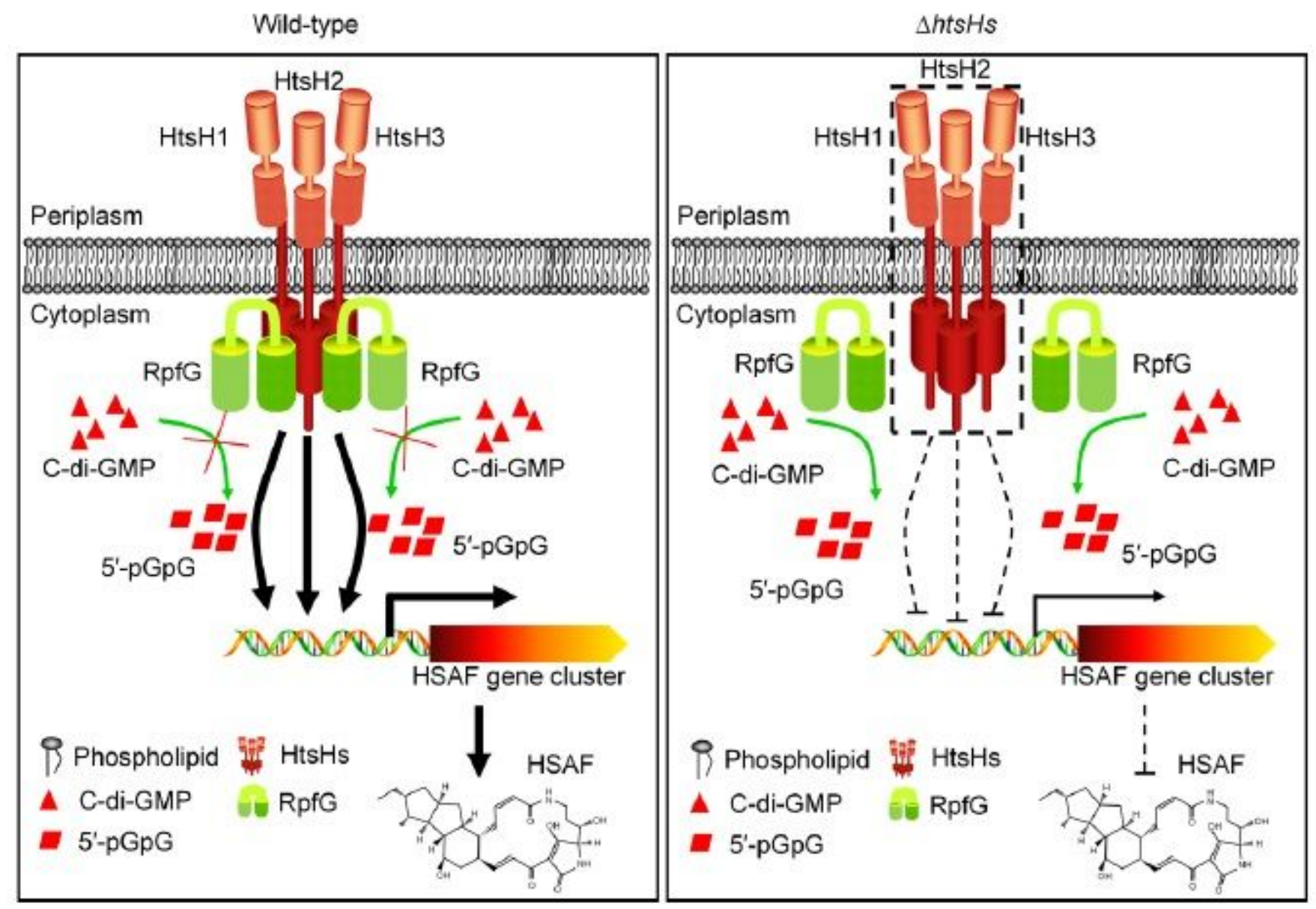

Figure 8

Schematic of the proposed RpfG directly interacting with three HyTCS proteins $(\mathrm{HtsH} 1, \mathrm{HtsH} 2$, and $\mathrm{HtsH} 3$ ) to regulate HSAF biosynthesis. The potential regulatory pathways and interactions of RpfG with $\mathrm{HtsH} 1, \mathrm{HtsH} 2$, and $\mathrm{HtsH} 3$ are proposed according to our observations and previous studies. RpfG and $\mathrm{HtsH} 1, \mathrm{HtsH} 2$, or HtsH3 interactions affect the PDE activity of RpfG. Phosphorylated $\mathrm{HtsH} 1, \mathrm{HtsH} 2$, and $\mathrm{HtsH} 3$ can directly target the promoter of HSAF biosynthesis genes to regulate HSAF production in L. enzymogenes.

\section{Supplementary Files}

This is a list of supplementary files associated with this preprint. Click to download. 
- Supportinginformation.docx 